\title{
An assessment of the carbon balance of Arctic tundra: comparisons among observations, process models, and atmospheric inversions
}

\author{
A. D. McGuire ${ }^{1}$, T. R. Christensen ${ }^{2,3}$, D. Hayes ${ }^{4}$, A. Heroult ${ }^{2}$, E. Euskirchen ${ }^{5}$, J. S. Kimball ${ }^{6}$, C. Koven ${ }^{7}$, P. Lafleur ${ }^{8}$, \\ P. A. Miller ${ }^{2}$, W. Oechel ${ }^{9}$, P. Peylin ${ }^{10}$, M. Williams ${ }^{11}$, and Y. Yi ${ }^{6}$ \\ ${ }^{1}$ U.S. Geological Survey, Alaska Cooperative Fish and Wildlife Research Unit, University of Alaska Fairbanks, Fairbanks, \\ AK, USA \\ ${ }^{2}$ Department of Earth and Ecosystem Science, Lund University, Lund, Sweden \\ ${ }^{3}$ Greenland Climate Research Centre, Nuuk, Greenland \\ ${ }^{4}$ Oak Ridge National Laboratory, Oak Ridge, TN, USA \\ ${ }^{5}$ Institute of Arctic Biology, University of Alaska Fairbanks, Fairbanks, AK, USA \\ ${ }^{6}$ Flathead lake Biological Station, Division of Biological Sciences, the University of Montana, Missoula, MT, USA \\ ${ }^{7}$ Lawrence Berkeley National Laboratory, Berkeley, CA, USA \\ ${ }^{8}$ Department of Geography, Trent University, Peterborough, ON, Canada \\ ${ }^{9}$ Department of Biology, San Diego State University, San Diego, CA, USA \\ ${ }^{10}$ Laboratoire Sciences Climat Environnement, Institut Pierre Simon Laplace, Paris, France \\ ${ }^{11}$ School of GeoSciences, University of Edinburgh, Edinburgh, UK
}

Correspondence to: A. D. McGuire (admcguire@alaska.edu)

Received: 23 January 2012 - Published in Biogeosciences Discuss.: 17 April 2012

Revised: 8 July 2012 - Accepted: 23 July 2012 - Published: 17 August 2012

\begin{abstract}
Although Arctic tundra has been estimated to cover only $8 \%$ of the global land surface, the large and potentially labile carbon pools currently stored in tundra soils have the potential for large emissions of carbon (C) under a warming climate. These emissions as radiatively active greenhouse gases in the form of both $\mathrm{CO}_{2}$ and $\mathrm{CH}_{4}$ could amplify global warming. Given the potential sensitivity of these ecosystems to climate change and the expectation that the Arctic will experience appreciable warming over the next century, it is important to assess whether responses of $\mathrm{C}$ exchange in tundra regions are likely to enhance or mitigate warming. In this study we compared analyses of $\mathrm{C}$ exchange of Arctic tundra between 1990 and 2006 among observations, regional and global applications of process-based terrestrial biosphere models, and atmospheric inversion models. Syntheses of flux observations and inversion models indicate that the annual exchange of $\mathrm{CO}_{2}$ between Arctic tundra and the atmosphere has large uncertainties that cannot be distinguished from neutral balance. The mean estimate from an ensemble of process-based model simulations suggests that Arctic tundra has acted as a sink for atmospheric
\end{abstract}

$\mathrm{CO}_{2}$ in recent decades, but based on the uncertainty estimates it cannot be determined with confidence whether these ecosystems represent a weak or a strong sink. Tundra was $0.6^{\circ} \mathrm{C}$ warmer in the 2000 s compared to the 1990 s. The central estimates of the observations, process-based models, and inversion models each identify stronger sinks in the 2000s compared with the 1990s. Some of the process models indicate that this occurred because net primary production increased more in response to warming than heterotrophic respiration. Similarly, the observations and the applications of regional process-based models suggest that $\mathrm{CH}_{4}$ emissions from Arctic tundra have increased from the 1990s to 2000s because of the sensitivity of $\mathrm{CH}_{4}$ emissions to warmer temperatures. Based on our analyses of the estimates from observations, process-based models, and inversion models, we estimate that Arctic tundra was a sink for atmospheric $\mathrm{CO}_{2}$ of $110 \mathrm{Tg} \mathrm{C} \mathrm{yr}^{-1}$ (uncertainty between a sink of $291 \mathrm{Tg} \mathrm{C} \mathrm{yr}^{-1}$ and a source of $80 \mathrm{TgC} \mathrm{yr}^{-1}$ ) and a source of $\mathrm{CH}_{4}$ to the atmosphere of $19 \mathrm{Tg} \mathrm{C} \mathrm{yr}^{-1}$ (uncertainty between sources of 8 and $29 \mathrm{TgC}^{-1}$ ). The suite of analyses conducted in this study indicate that it is important to reduce uncertainties in 
the observations, process-based models, and inversions in order to better understand the degree to which Arctic tundra is influencing atmospheric $\mathrm{CO}_{2}$ and $\mathrm{CH}_{4}$ concentrations. The reduction of uncertainties can be accomplished through (1) the strategic placement of more $\mathrm{CO}_{2}$ and $\mathrm{CH}_{4}$ monitoring stations to reduce uncertainties in inversions, (2) improved observation networks of ground-based measurements of $\mathrm{CO}_{2}$ and $\mathrm{CH}_{4}$ exchange to understand exchange in response to disturbance and across gradients of climatic and hydrological variability, and (3) the effective transfer of information from enhanced observation networks into process-based models to improve the simulation of $\mathrm{CO}_{2}$ and $\mathrm{CH}_{4}$ exchange from Arctic tundra to the atmosphere.

\section{Introduction}

The distribution of the Arctic tundra biome covers approximately $8 \%$ of the global land surface, largely north of the boreal forest treeline (McGuire et al., 1997). The exact location of the biome's southern border is subjective, with the transition between closed boreal forest and treeless tundra up to several hundred kilometers wide in regions of low topographic relief (Vlassova, 2002; Callaghan et al., 2005). Climate in the Arctic is harsh, characterized by cold winters and cool summers, with mean July temperatures below $\sim 12{ }^{\circ} \mathrm{C}$ (Callaghan et al., 2005) and annual mean temperatures typically below $-10^{\circ} \mathrm{C}$ (New et al., 1999). Consequently, plant growth is restricted to a relatively short growing season on the order of three months or less during the boreal summer. The tundra biome is home to approximately 1800 species of vascular plants and has less species diversity than more temperate biomes (Asner et al., 2003; Callaghan et al., 2005). The stature of vascular plant species is limited by environmental conditions, with trees almost entirely absent and woody plant species restricted largely to shrubs and dwarf shrubs. In addition to vascular plant species, nonvascular mosses and lichens play a very important role in the structure and function of tundra ecosystems. Frozen soils are prevalent in northern high latitudes and there is a gradient of continuous to discontinuous permafrost from north to south. Most of the tundra biome is underlain by continuous permafrost. The spatial and temporal dynamics of permafrost and periodic disturbance are crucial in shaping the arctic landscape and its heterogeneity, with important consequences for the areal extent of wetlands and the exchange of carbon dioxide $\left(\mathrm{CO}_{2}\right)$ and methane $\left(\mathrm{CH}_{4}\right)$.

Future climate warming is predicted to be pronounced over the Arctic, especially during winter and spring. The arctic autumn and winter are expected to warm between 3 and $6^{\circ} \mathrm{C}$ by 2080 (SWIPA Assessment Executive Summary, 2011), which is expected to lead to longer growing seasons, thawing of permafrost, warming and deepening of the soil active layer, and large changes in hydrology. These changes are likely to substantially affect tundra ecosystem structure and function. In fact, there is increasing evidence that physical and ecological changes are already occurring throughout the tundra biome (Serreze et al., 2003, Hinzman et al., 2005; McDonald et al., 2004; Piao et al., 2008, 2011; Post et al., 2009; Rawlins et al., 2010; Rowland et al., 2010; Beck and Goetz, 2011; Kim et al., 2012).

The large and potentially labile carbon (C) pools currently stored in Arctic soils (Ping et al., 2008; Tarnocai et al., 2009) have the potential to be emitted as radiatively active greenhouse gases in the form of both $\mathrm{CO}_{2}$ and $\mathrm{CH}_{4}$ under warmer conditions (Schuur et al., 2008, 2011; Chapin et al., 2008; McGuire et al., 2009; Schaefer et al., 2011; Koven et al., 2011). Whether the emissions of $\mathrm{CO}_{2}$ from tundra soils tends to amplify or mitigate global warming depends on the degree to which $\mathrm{C}$ accumulation in tundra plants responds to warming (Sitch et al., 2007). This balance determines whether the tundra is a source or sink of $\mathrm{CO}_{2}$. Changes in the emissions of $\mathrm{CH}_{4}$ may also affect the degree to which tundra amplifies or mitigates global warming. While $\mathrm{CH}_{4}$ has only a small role on the mass balance of $\mathrm{C}$ between the atmosphere and tundra, it is a highly potent greenhouse gas. Changes in $\mathrm{CH}_{4}$ emissions are likely to be strongly linked to changes in hydrology (Merbold et al., 2009). Current emissions of $\mathrm{CH}_{4}$ are difficult to quantify due to substantial variability in time and space due to variations in the environment associated with topography, hydrology, and soil chemistry.

Because of the substantial changes that are already affecting the structure and function of Arctic tundra, it is important to assess how $\mathrm{C}$ exchange of Arctic tundra has been changing in recent decades. The response of $\mathrm{C}$ dynamics of Arctic tundra to environmental change can be evaluated through a synthesis of (1) observations of $\mathrm{C}$ exchange with the atmosphere, (2) the application of process-based models, and (3) the analysis of atmospheric inversion models of $\mathrm{C}$ exchange with the atmosphere. Each of these scaling approaches has it strengths, weaknesses, and limitations in assessing the carbon dynamics of Arctic tundra. In this paper we compare analyses of $\mathrm{C}$ dynamics of Arctic tundra in the two most recent decades among the three scaling approaches to gain insight on how $\mathrm{C}$ exchange of Arctic tundra may be responding to ongoing environmental changes. The analysis in this paper represents the Arctic tundra contribution to the Global Carbon Project's REgional Carbon Cycle and Assessment Processes (RECCAP) synthesis (Canadell et al., 2011).

\section{Methods}

\subsection{Estimates from flux observations}

Methods for ground-based observation of the exchange of C between land and atmosphere face great challenges in Arctic environments. The challenges include (1) comprehensive spatial coverage in the face of a heterogeneous landscape 
mosaic that is often characterized by "hot spots"; (2) continuous sampling to achieve full year-round estimates of carbon dynamics; (3) high temporal resolution to sample episodic exchanges of $\mathrm{CO}_{2}$ and $\mathrm{CH}_{4}$; and (4) collection of $\mathrm{C}$ exchange data without line power in remote conditions.

A single technique is not available that meets all of these challenges. Currently, manual chambers, automatic chambers, and eddy covariance towers are the primary techniques being used to measure $\mathrm{C}$ exchange between tundra with the atmosphere. For $\mathrm{CO}_{2}$ flux measurements, these sampling techniques are linked to infrared gas analyzers that measure $\mathrm{CO}_{2}$ concentrations. For $\mathrm{CH}_{4}$, the field technology is less developed, and has relied on gas sample collection in the field, with laboratory estimates of $\mathrm{CH}_{4}$ concentrations using gas chromatographs. Eddy covariance measurement systems have recently been developed that allow continuous direct $\mathrm{CH}_{4}$ concentration estimates in the field, and these are starting to be more commonly used to measure $\mathrm{CH}_{4}$ exchange (e.g., Rinne et al., 2007; Jackowicz-Korczynski et al., 2010). In Table 1 we compare the relative performance of these methods for a number of requirements and considerations. Because typical tundra areas are heterogeneous, it is often necessary to employ chamber methods of measurement to differentiate the $\mathrm{C}$ exchange for the individual components (e.g., soil, moss, and vascular plants) and to better understand the underlying processes of land-atmosphere C exchange. Chamber-based measurements complement towerbased measurements that more effectively integrate across a heterogeneous landscape. In Supplement 1 we have compiled approximately 250 estimates from 120 published papers of the mean exchange of $\mathrm{CO}_{2}$ and $\mathrm{CH}_{4}$ between Arctic tundra and the atmosphere at growing season, winter season, and annual time scales based on published observational studies. The exchange of $\mathrm{CO}_{2}$ with the atmosphere is reported as net ecosystem exchange (NEE), i.e., net land-atmosphere $\mathrm{CO}_{2}$ flux, in which a positive NEE represents a loss of $\mathrm{CO}_{2}$ from tundra to the atmosphere. Similarly, the exchange of $\mathrm{CH}_{4}$ is reported as a positive flux when the net exchange is to the atmosphere and as a negative flux when the net exchange is into the ecosystem. Both $\mathrm{CO}_{2}$ and $\mathrm{CH}_{4}$ estimates are reported in units of $\mathrm{C}$. In this study we used only estimates of $\mathrm{CO}_{2}$ and $\mathrm{CH}_{4}$ exchange from Supplement 1 for the time period between 1990 and 2009 unless stated otherwise.

\subsection{Estimates from process-based models}

The spatial domain of Arctic tundra we considered in this study (Fig. 1) was defined by the Regional Carbon Cycle Assessment and Processes (RECCAP) Activity. It is important to note that the spatial domain of Arctic tundra was defined from an atmospheric perspective as a region that could potentially be resolved by the applications of inversion models. The region extends into boreal forest in some areas (for example in western North America). In this study we compare the carbon dynamics of Arctic tundra between 1990
Table 1. A summary of the technical performance different flux measurement techniques. ++ means high performance, + means adequate performance, - means less than adequate performance, and -- means poor performance.

\begin{tabular}{llll}
\hline & $\begin{array}{l}\text { Eddy } \\
\text { covariance }\end{array}$ & $\begin{array}{l}\text { Automatic } \\
\text { chambers }\end{array}$ & $\begin{array}{l}\text { Manual } \\
\text { chambers }\end{array}$ \\
\hline $\begin{array}{l}\text { Steady state, } \\
\text { undisturbed } \\
\text { measurement }\end{array}$ & ++ & + l- & - \\
\hline $\begin{array}{l}\text { Integration over } \\
\text { spatial } \\
\text { variability }\end{array}$ & ++ & $\begin{array}{l}\text {-(quantity } \\
\text { of chambers } \\
\text { vs. mosaic) }\end{array}$ & $\begin{array}{l}\text { of chambers } \\
\text { vs. mosaic) }\end{array}$ \\
\hline $\begin{array}{l}\text { Direct measure- } \\
\text { ment of small } \\
\text { scale spatial } \\
\text { variability }\end{array}$ & -- & + & ++ \\
\hline $\begin{array}{l}\text { Tracking tempo- } \\
\text { ral variability }\end{array}$ & ++ & ++ & $-($ campaigns \\
& & & $\begin{array}{l}\text { as basis for } \\
\text { modeling) }\end{array}$ \\
\hline $\begin{array}{l}\text { Costs } \\
\text { Workload }\end{array}$ & ++ & +- & ++ \\
\hline $\begin{array}{l}\text { Performance } \\
\text { under all climate } \\
\text { conditions }\end{array}$ & $+/-$ & $+/-$ & ++ \\
\hline
\end{tabular}

and 2006 estimated by regional applications of three models that have focused on representing processes in ecosystems underlain by permafrost: LPJ-Guess WHyMe (Smith et al., 2001; Wania et al., 2009a, b, 2010; Hickler et al., 2012), Orchidee (Koven et al., 2009, 2011), and version 6 of the Terrestrial Ecosystem Model (TEM6; McGuire et al., 2010; Hayes et al., 2011). For evaluating the production estimates of the three regional process-based models, we have also included the Terrestrial Carbon Flux (TCF) model (Kimball et al., 2009) in the regional process-based model analysis. The general features of the models are compared in Table 2 (see Supplement 2 for more details).

The TCF is unique among the models in that it is partially driven by satellite-based vegetation gross primary production (GPP) estimates from the NASA Moderate Resolution Imaging Spectroradiometer (MODIS) for the period between 2000 and 2009 (Zhao and Running, 2010). The MODIS (MOD17) GPP estimates are used to derive vegetation net primary production (NPP), while heterotrophic respiration (RH) is determined from a simulated surface $(<10 \mathrm{~cm}$ depth) soil organic carbon pool and dynamic soil moisture and temperature constraints to litter decomposition. The TCF does not account for other carbon emission sources, including fire disturbance, so NEE is derived as the residual difference between NPP and RH, and assumed equivalent to net ecosystem production (NEP). The TCF calculations assume dynamic 


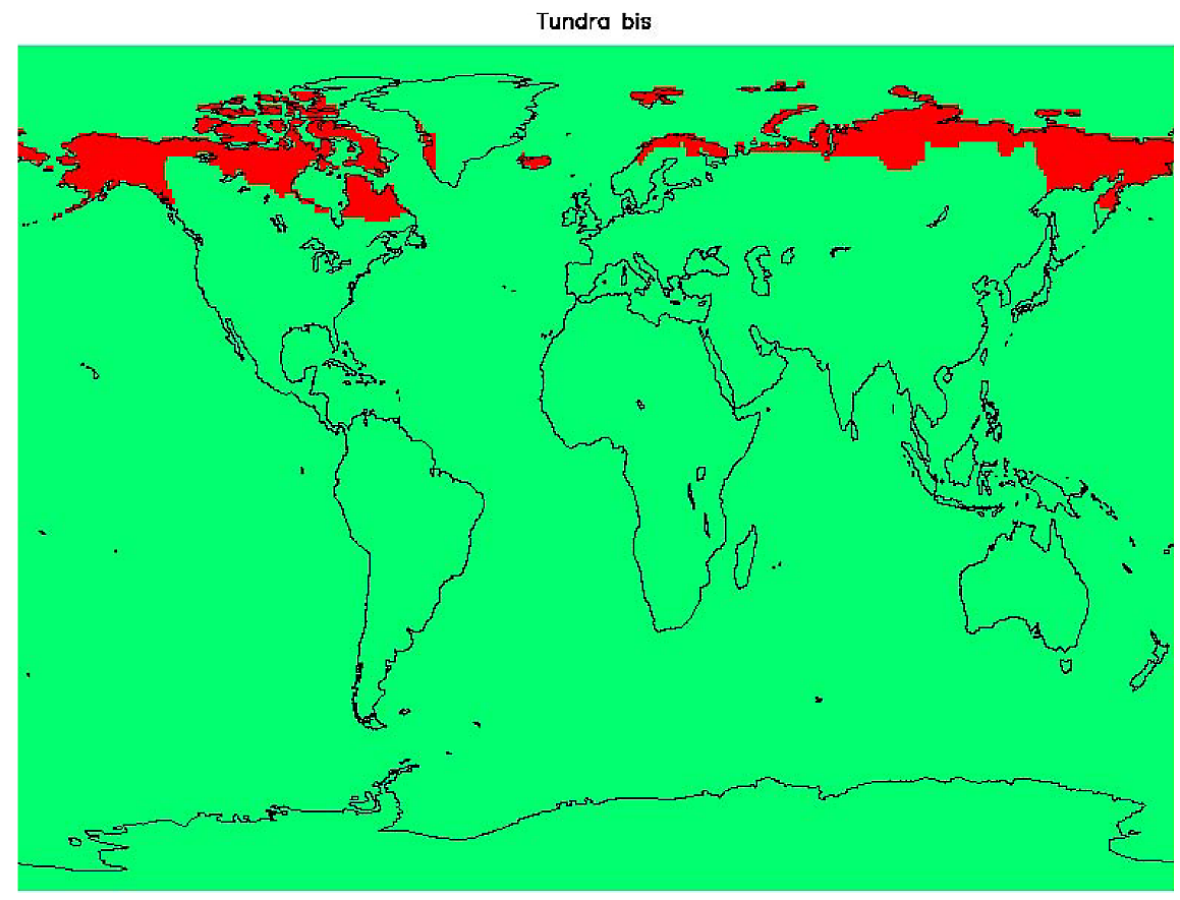

Fig. 1. The Arctic Tundra RECCAP Region.

steady-state conditions between NPP and RH so that estimated NEE/NEP has no trend over the decade from 2000 to 2009. The other three models were driven in a prognostic fashion by atmospheric $\mathrm{CO}_{2}$ and climate data of their own choosing over the simulation period. Because of each model's choice of climate data, both LPJ-Guess WHyMe and TEM6 produced estimates for only the 1990-2006 time period. Therefore, we only compare 2000-2006 among the models in the most recent decade. See Supplement 2 for more details on the application of the regional models in this study.

All models estimate GPP, NPP, RH, and NEP. Both LPJGuess and TEM6 make estimates of losses of carbon to the atmosphere associated with fire and biogenic $\mathrm{CH}_{4}$ emissions. In addition, TEM6 also calculates ecosystem losses of carbon from the export of harvested products and dissolved organic carbon. For each of the models we also calculate the net ecosystem carbon balance (NCB) as the sum of NPP and the atmospheric and export losses. The sign conventions for NEP and NCB are positive for a net flux of carbon into the ecosystem. We also report net $\mathrm{CO}_{2}-\mathrm{C}$ exchange with a sign convention of positive representing a source to the atmosphere and negative representing a sink into tundra ecosystems. In this study, we compare the mean $\mathrm{C}$ budget estimated from 1990-1999 and 2000-2006 among simulations of LPJGuess WHyMe, Orchidee, and TEM6. We also report net $\mathrm{CO}_{2}-\mathrm{C}$ exchange for each of the models as previously defined. We also provide mean GPP and NPP estimates simulated by TCF for 2000-2006. To explore issues involving the mean seasonal cycle of $\mathrm{CO}_{2}$ exchange, we compare the mean monthly flux estimates for GPP, NPP, RH, and NEP for 1990-2006 simulated by LPJ-Guess, Orchidee, and TEM6, and for 2000-2006 simulated by TCF. We also compare interannual variability for estimates of GPP, NPP, RH, NEP, other atmospheric losses, export losses, and NCB among the models. To explore the importance of changing climate on the regional applications of the process-based models, we conducted additional simulations that were driven by constant climate keeping all other drivers unchanged. The constant climate for the three models was based on the 19011930 climate used to drive their transient simulations. We estimate the effect of a changing climate on NPP, RH, and NEP between 1990 and 2006 by subtracting the estimates of the constant climate simulation of each model from that of the corresponding transient climate simulation.

The RECCAP activity is also comparing the mean $\mathrm{C}$ budgets for the 1990s and 2000s estimated by a suite of global applications of dynamic global vegetation models (DGVMs). These DGVM applications were conducted as part of the Trendy project (http://dgvm.ceh.ac.uk) to examine trends in the net land C exchange over the period 1980-2009. In this study we compare the mean $\mathrm{C}$ budget of these global applications for the Arctic tundra region of this study for the time periods 1990-1999 and 2000-2006. The DGVM applications compared in this study include contributions from CLM4C (Lawrence et al., 2011), CLM4CN (Thornton et al., 2007, 2009; Bonan and Levis 2010; Lawrence et al., 2011), Hyland (Levy et al., 2004), LPJ (Sitch et al., 2003), LPJGuess (Smith et al., 2001), O-CN (v0.74; Zaehle and Friend, 
Table 2. Description of process-based models compared in this study. See Supplement 2 for additional details.

\begin{tabular}{|c|c|c|c|c|c|}
\hline & $\begin{array}{l}\text { Model Description } \\
\text { Recent Arctic } \\
\text { Applications }\end{array}$ & $\begin{array}{l}\text { LPJ-Guess WHyMe } \\
\text { Smith et al. (2001) } \\
\text { Wania et al. (2009a) } \\
\text { Wania et al. (2009b) } \\
\text { Wania et al. (2010) }\end{array}$ & $\begin{array}{l}\text { Orchidee } \\
\text { Koven et al. (2009) } \\
\text { Koven et al. (2011) }\end{array}$ & $\begin{array}{l}\text { TCF } \\
\text { Kimball et al. (2009) }\end{array}$ & $\begin{array}{l}\text { TEM6 } \\
\text { Hayes et al. (2011) } \\
\text { McGuire et al. (2010) }\end{array}$ \\
\hline \multicolumn{6}{|l|}{ Scale } \\
\hline Temporal & $\begin{array}{l}\text { Resolution } \\
\text { Application }\end{array}$ & $\begin{array}{l}\text { Daily } \\
\text { Daily to Century }\end{array}$ & $\begin{array}{l}30 \mathrm{~min} \\
\text { Diurnal to multi-seasonal } \\
\text { (Century application) }\end{array}$ & $\begin{array}{l}\text { Daily } \\
\text { Daily to Decadal }\end{array}$ & $\begin{array}{l}\text { Month } \\
\text { Seasonal to Century }\end{array}$ \\
\hline Spatial & $\begin{array}{l}\text { Resolution } \\
\text { Application }\end{array}$ & $\begin{array}{l}0.5^{\circ} \\
\text { Plot - Globe }\end{array}$ & $\begin{array}{l}2^{\circ} \\
\text { Plot - Globe }\end{array}$ & $\begin{array}{l}25 \mathrm{~km} \\
\text { Plot - Region }\end{array}$ & $\begin{array}{l}0.5^{\circ} \\
\text { Plot - Globe }\end{array}$ \\
\hline \multicolumn{6}{|l|}{ Structure } \\
\hline Vegetation & & Dynamic & Prescribed & Prescribed & Prescribed \\
\hline Litter/Soil Pools & & $1 / 3$ & $4 / 3$ & 3 & 2 \\
\hline Microbial Pools & & No & No & No & No \\
\hline \multicolumn{6}{|l|}{ Processes } \\
\hline \multirow[t]{4}{*}{ General } & Photosynthesis & $\begin{array}{l}\text { Farquhar et al. (1980) } \\
\text { modified by Haxeltine and } \\
\text { Prentice (1996) }\end{array}$ & Farquhar et al. 1980 & $\begin{array}{l}\text { MODIS MOD17 production } \\
\text { efficiency model (Running et } \\
\text { al., 2004) }\end{array}$ & $\begin{array}{l}\text { GPP based on multiple lim- } \\
\text { iting factors (see McGuire } \\
\text { et al., 1997) }\end{array}$ \\
\hline & $\begin{array}{l}\text { Heterotrophic } \\
\text { Respiration (RH) }\end{array}$ & $\begin{array}{l}\text { Dependent on soil carbon, } \\
\text { soil temperature and moisture } \\
\text { (Smith et al., 2001). Follows } \\
\text { Wania et al. (2009a, b) for } \\
\text { peatlands. }\end{array}$ & $\begin{array}{l}Q_{10} \text { of } 2 \text { with respect } \\
\text { to each soil layer } \\
\text { temperature for unfrozen } \\
\text { soil layers; linear drop } \\
\text { off to } 0 \mathrm{RH} \text { between } \\
0 \text { and }-2^{\circ} \mathrm{C}\end{array}$ & $\begin{array}{l}\text { Dependent on surface } \\
(<10 \mathrm{~cm}) \text { soil organic } \\
\text { carbon, surface soil } \\
\text { temperature and moisture } \\
\text { (Kimball et al., 2009) }\end{array}$ & $\begin{array}{l}\text { Dependent on soil organic } \\
\text { carbon, soil moisture, soil } \\
\text { temperature (see Zhuang et } \\
\text { al., 2003) }\end{array}$ \\
\hline & Fire & $\begin{array}{l}\text { Yes. On upland soils only, not } \\
\text { in peatlands. }\end{array}$ & No & No & Yes \\
\hline & $\mathrm{C}: \mathrm{N}$ dynamics & $\begin{array}{l}\text { Optimal } \mathrm{N} \text { allocation to } \\
\text { canopy assumed (Haxeltine } \\
\text { and Prentice, 1996) }\end{array}$ & No & No & Yes \\
\hline \multirow[t]{4}{*}{$\begin{array}{l}\text { Especially Relevant to } \\
\text { Arctic Tundra } \\
\text { Ecosystems }\end{array}$} & $\begin{array}{l}\text { Non-Vascular Plants } \\
\text { (Mosses/Lichens) }\end{array}$ & $\begin{array}{l}\text { Yes, but mosses only } \\
\text { represented in peatlands }\end{array}$ & No & No & $\begin{array}{l}\text { Yes in soil thermal dynam- } \\
\text { ics, no in biogeochemical } \\
\text { dynamics }\end{array}$ \\
\hline & Permafrost & $\begin{array}{l}\text { Freeze-thaw processes as } \\
\text { described in Wania et } \\
\text { al. }(2009 a, b)\end{array}$ & $\begin{array}{l}\text { Freeze/thaw processes } \\
\text { described in Poutou et } \\
\text { al. (2004); permafrost } \\
\text { carbon pools described in } \\
\text { Koven et al. (2009) }\end{array}$ & No & $\begin{array}{l}\text { Yes, see Zhuang et } \\
\text { al. (2001, 2003) and } \\
\text { Hayes et al. (2011) }\end{array}$ \\
\hline & Lateral Hydrology & No & No & No & No \\
\hline & Methane & $\begin{array}{l}\text { Yes, as described in Wania et } \\
\text { al. (2010) }\end{array}$ & No & No & $\begin{array}{l}\text { Yes, see Zhuang et } \\
\text { al. }(2004,2007)\end{array}$ \\
\hline
\end{tabular}

2010), SDGVM (Woodward et al., 1995; Woodward and Lomas, 2004), and TRIFFID (Cox, 2001). The models used a common protocol (http://dgvm.ceh.ac.uk) applying CRUNCEP climatology over the period 1901-2009. Note that the global application of LPJ-Guess is quite different from the regional application of LPJ-Guess WHyMe, which represents processes relevant to Arctic tundra function and structure including (1) soil water freezing; (2) Arctic shrub and open ground plant functional types (e.g., Sphagnum mosses and tundra graminoids); (3) peatland hydrology, decomposition, and plant functional types; (4) a methane module for peatlands; and (5) root exudates (see Supplement 2 for details).

\subsection{Estimates from inversion-based models}

We also analyzed the mean land-atmosphere $\mathrm{CO}_{2}-\mathrm{C}$ exchange for the Arctic tundra domain from a set of ten inversion models that were applied in support of RECCAP analyses (Gurney, 2012). The inversion models include C13_CCAM_law, C13_MATCH_rayner, CTRACKER_EU, CTRACKER_US, JENA_s96_v3.3, JMA_2010, LSCE_an_v2.1, LSCE_var_v1.0, NICAM_niwa_woaia, and rigc_patra. Among these inversion models, the applications span the time period from 1985-2009. However, the period of application is highly variable among the models. We report the mean NEE estimate for Arctic tundra from 1990-1999 and 2000-2006 for eight of the applications of these inversion models; we do not report the results from CTRACKER_EU or CTRACKER_US as these models did not start making estimates until 2001. We report the mean season cycle of $\mathrm{CO}_{2}-\mathrm{C}$ exchange estimates based on the time period of application of each of the ten models. Similarly, we report the interannual variability of NEE anomalies across 
the time period of application of each of the ten models. We include CTRACKER_EU and CTRACKER_US in the seasonal cycle and interannual variability analyses.

\section{Results}

\subsection{Estimates based on flux observations}

\subsection{1 $\mathrm{CO}_{2}$ exchange}

Most direct observational studies of the exchange of $\mathrm{CO}_{2}$ between tundra and the atmosphere have been conducted during the summer growing season. These studies generally indicate that Arctic tundra has been a sink for atmospheric $\mathrm{CO}_{2}$ during the summer in all subregions of the Arctic (i.e., NEE is largely negative; Fig. 2) and that there has not been a substantial change in the sink strength between the 1990s and 2000s (Table 3). While it appears from Table 3 that the summer sink strength in Eurasia has more than doubled since 2000 (from -25 to $-73 \mathrm{~g} \mathrm{C} \mathrm{m}^{-2}$ summer $^{-1}$ ), the mean estimates are not significantly different as the $95 \%$ confidence limits, since 2000 overlap the $95 \%$ confidence limits for the 1990s. The existing observations suggest that wet (lowland) tundra is a sink for $\mathrm{CO}_{2}$ during the growing season ( $-43 \mathrm{~g} \mathrm{C} \mathrm{m}^{-2}$ summer $^{-1}$ ), while dry/mesic (upland) tundra tends to be a growing season source of $\mathrm{CO}_{2}$ to the atmosphere with a confidence interval that overlaps neutral balance (Table 4).

Only a handful of studies have estimated the exchange of $\mathrm{CO}_{2}$ in winter, as there are considerable challenges in maintaining accurate flux measurements outside the growing season. The available estimates indicate that tundra ecosystems are wintertime sources of $\mathrm{CO}_{2}$ to the atmosphere (Fig. 2, Table 3). Given that few studies have been conducted, it does not appear that the strength of sources differs among subregions ( 29 to $41 \mathrm{~g} \mathrm{C} \mathrm{m}^{-2}$ winter $^{-1}$; Table 3 ). Also, the scarcity of winter exchange data does not allow us to evaluate if there are differences in source strength between the 1990s and 2000s. The existing observations suggest that there is little difference in the source strength of $\mathrm{CO}_{2}$ during the winter between wet and dry/mesic tundra $\left(31 \mathrm{~g} \mathrm{C} \mathrm{m}^{-2}\right.$ winter $^{-1}$, Table 4).

There are a growing number of observationally based studies that estimate annual $\mathrm{CO}_{2}$ exchange between tundra and the atmosphere. In general, the range of variability among estimates is scattered around neutral annual $\mathrm{CO}_{2}$ exchange in all subregions (Fig. 2). In North America, the data suggest that tundra ecosystems tended to be annual sources of $\mathrm{CO}_{2}$ to the atmosphere prior to $2000\left(29 \mathrm{~g} \mathrm{C} \mathrm{m}^{-2} \mathrm{yr}^{-1}\right)$, but have been weak sinks since $2000\left(-3 \mathrm{~g} \mathrm{C} \mathrm{m}^{-2} \mathrm{yr}^{-1}\right.$; Table 3$)$. The existing observations suggest that wet tundra is a strong sink for $\mathrm{CO}_{2}$ annually, while dry/mesic tundra tends to be an annual source of $\mathrm{CO}_{2}$ to the atmosphere with a confidence interval that overlaps neutral balance (Table 4).
Based on the mean and range of NEE observations reported in Table 3 for the different geographical regions of the Arctic, we developed first order estimates of NEE and ranges in uncertainty in those estimates for Arctic tundra between 1990 and 2009 (see Supplement 3 for details). This analysis suggests that tundra was source of $138 \mathrm{Tg} \mathrm{C} \mathrm{yr}^{-1}$ as $\mathrm{CO}_{2}$ to the atmosphere in the $1990 \mathrm{~s}$, with a range of uncertainty between a $-102 \mathrm{Tg} \mathrm{C} \mathrm{yr}^{-1}$ sink and a $378 \mathrm{Tg} \mathrm{C} \mathrm{yr}^{-1}$ source. In contrast, the analysis suggests that tundra was a $-202 \mathrm{Tg} \mathrm{C} \mathrm{yr}^{-1}$ sink in the 2000 s with an uncertainty range between a $-628 \mathrm{TgC} \mathrm{yr}^{-1}$ sink and $224 \mathrm{TgC} \mathrm{yr}^{-1}$ source. Across the two decades, we estimate that tundra was a sink of $-103 \mathrm{Tg} \mathrm{C} \mathrm{yr}^{-1}$ with an uncertainty between

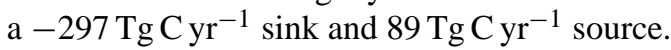

\subsection{2 $\mathrm{CH}_{4}$ exchange}

Similar to data on $\mathrm{CO}_{2}$ exchange, most of the studies of the exchange of $\mathrm{CH}_{4}$ between tundra and the atmosphere have been conducted during the summer growing season. These studies generally indicate that Arctic tundra is a substantial source of $\mathrm{CH}_{4}$ to the atmosphere during the summer (Fig. 2) and that there has not been a substantial change in the strength of the source between the 1990s (3.0 to $7.8 \mathrm{~g} \mathrm{CH}_{4}-\mathrm{C} \mathrm{m}^{-2}$ summer $^{-1}$ across regions) and 2000s (1.4 to $12.5 \mathrm{~g} \mathrm{CH}_{4}-\mathrm{C} \mathrm{m}^{-2}$ summer $^{-1}$ across regions; Table 3 ). However, the existing observations suggest that there are differences among different tundra types as mean summer emissions of $\mathrm{CH}_{4}$ for wet tundra are $9.2 \mathrm{~g} \mathrm{C} \mathrm{m}^{-2}$ compared with $0.8 \mathrm{~g} \mathrm{C} \mathrm{m}^{-2}$ for dry/mesic tundra with no overlap in the confidence intervals (Table 4). There are only two studies that have estimated the exchange of $\mathrm{CH}_{4}$ in winter, and these studies indicate that tundra ecosystems are a weak source of around 3.0 (range 0.1 to 6.0 ) $\mathrm{g} \mathrm{CH}_{4}-\mathrm{C} \mathrm{m}^{-2}$ winter $^{-1}$ to the atmosphere. The comparison of tundra $\mathrm{CH}_{4}$ emissions between summer and annual estimates suggests that $\mathrm{CH}_{4}$ emissions in winter supports this range, as annual fluxes are $5.4 \mathrm{~g} \mathrm{CH}_{4}-\mathrm{C} \mathrm{m}^{-2}$ higher than summer fluxes in wet tundra vs. $1.5 \mathrm{~g} \mathrm{CH}_{4}-\mathrm{C} \mathrm{m}^{-2}$ higher in dry tundra (Table 4).

Based on the mean and range of $\mathrm{CH}_{4}$ observations reported in Table 3 for the different geographical regions of the Arctic, we developed estimates of $\mathrm{CH}_{4}$ emissions and ranges in uncertainty in those estimates for Arctic tundra before and since 2000 (see Supplement 3 for details). This analysis suggests that tundra emitted $10 \mathrm{Tg} \mathrm{Cyr}^{-1}$ as $\mathrm{CH}_{4}$ to the atmosphere in the 1990s, with a range of uncertainty between -1 and $22 \mathrm{Tg} \mathrm{Cyr}^{-1}$. The analysis suggests that tundra was stronger emitter of $\mathrm{CH}_{4}$ during the $2000 \mathrm{~s}\left(20 \mathrm{Tg} \mathrm{C} \mathrm{yr}^{-1}\right)$, but the uncertainties since 2000 are much larger than in the 1990s (between a sink of 11 and a source of $51 \mathrm{Tg} \mathrm{C} \mathrm{yr}^{-1}$ ). We suspect that the larger uncertainty in the 2000s is associated with more measurements of $\mathrm{CH}_{4}$ across a greater diversity of tundra vegetation types. Across the two decades, our analysis indicates that tundra emitted $11 \mathrm{Tg} \mathrm{Cyr}^{-1}$ as $\mathrm{CH}_{4}$ with a range

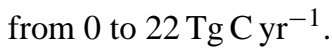


Table 3. Summary of observationally based estimates of mean net $\mathrm{CO}_{2}-\mathrm{C}$ and $\mathrm{CH}_{4}-\mathrm{C}$ exchange from Arctic tundra to the atmosphere $\left(\mathrm{g} \mathrm{C} \mathrm{m}^{-2}\right.$ season $\left.^{-1}\right)$ for different subregions.

\begin{tabular}{|c|c|c|c|c|}
\hline Time Period & North America & North Atlantic & Northern Europe & Eurasia \\
\hline \multicolumn{5}{|c|}{$\mathrm{CO}_{2}$ Exchange } \\
\hline \multicolumn{5}{|l|}{ Summer } \\
\hline $\begin{array}{l}1990-1999 \\
2000-2009 \\
1990-2009\end{array}$ & $\begin{array}{r}-7\left(52^{1} ;-22 \text { to } 7^{2}\right) \\
-18(28 ;-39 \text { to } 3) \\
-11(80 ;-23 \text { to } 1)\end{array}$ & $\begin{array}{r}-32(9 ;-58 \text { to }-5) \\
-53(12 ;-90 \text { to }-16) \\
-44(21 ;-66 \text { to }-21)\end{array}$ & $\begin{array}{r}-98(4 ;-127 \text { to }-68) \\
-92(5 ;-220 \text { to } 36) \\
-94(9 ;-151 \text { to }-38)\end{array}$ & $\begin{array}{l}-25(18 ;-50 \text { to }-1) \\
-73(12 ;-141 \text { to }-4) \\
-44(30 ;-74 \text { to }-14)\end{array}$ \\
\hline \multicolumn{5}{|l|}{ Winter } \\
\hline 1990-2009 & $31(9 ; 15$ to 47$)$ & - & $41(3 ; 11$ to 71$)$ & $29(2 ;-13$ to 73$)$ \\
\hline \multicolumn{5}{|l|}{ Annual } \\
\hline $\begin{array}{l}1990-1999 \\
2000-2009 \\
1990-2009\end{array}$ & $\begin{array}{r}29(9 ; 2 \text { to } 57) \\
-3(14 ;-28 \text { to } 21) \\
10(23 ;-10 \text { to } 28) \\
\end{array}$ & $-68(4 ;-213$ to 78$)$ & $\begin{array}{r}-25(6 ;-63 \text { to }-14) \\
-19(33 ;-30 \text { to }-8) \\
-20(39 ;-30 \text { to }-10)\end{array}$ & $-82(6 ;-134$ to -30$)$ \\
\hline \multicolumn{5}{|c|}{$\mathrm{CH}_{4}$ Exchange } \\
\hline \multicolumn{5}{|l|}{ Summer } \\
\hline $\begin{array}{l}1990-1999 \\
2000-2009 \\
1990-2009\end{array}$ & $\begin{array}{c}2.4(10 ; 0.7 \text { to } 4.2) \\
1.4(9 ;-0.2 \text { to } 2.9) \\
1.9(19 ; 0.8 \text { to } 3.0)\end{array}$ & $\begin{array}{r}- \\
- \\
3.1(3 ; 2.3 \text { to } 3.8)\end{array}$ & $\begin{array}{r}7.8(13 ; 1.4 \text { to } 14.2) \\
12.5(10 ; 1.9 \text { to } 23.0) \\
9.9(23 ; 4.5 \text { to } 15.2)\end{array}$ & $\begin{array}{r}3.0(15 ;-0.4 \text { to } 6.5) \\
5.1(29 ; 1.6 \text { to } 8.6) \\
4.4(44 ; 1.9 \text { to } 6.9)\end{array}$ \\
\hline \multicolumn{5}{|l|}{ Annual } \\
\hline $\begin{array}{l}1990-1999 \\
2000-2009 \\
1990-2009\end{array}$ & $\begin{array}{r}4.4(24 ; 1.4 \text { to } 7.4) \\
16.9(2 ;-12.0 \text { to } 45.7) \\
5.4(26 ; 1.9 \text { to } 8.9)\end{array}$ & $\begin{array}{l}- \\
- \\
-\end{array}$ & $\begin{array}{r}15.0(3 ;-18.3 \text { to } 48.3) \\
11.3(27 ; 6.6 \text { to } 16.0) \\
11.7(30 ; 7.2 \text { to } 16.1)\end{array}$ & $\begin{array}{l}- \\
8.2(7,-1.8 \text { to } 18.1) \\
8.2(7 ;-1.8 \text { to } 18.1)\end{array}$ \\
\hline
\end{tabular}

1 Number of site-year estimates.

$295 \%$ confidence interval.

Table 4. Summary of observationally based estimates of mean net $\mathrm{CO}_{2}-\mathrm{C}$ and $\mathrm{CH}_{4}-\mathrm{C}$ exchange from Arctic tundra to the atmosphere $\left(\mathrm{g} \mathrm{C} \mathrm{m}^{-2}\right.$ season $\left.^{-1}\right)$ for different tundra types.

\begin{tabular}{lrr}
\hline Time Period & Wet Tundra & Dry/Mesic Tundra \\
\hline $\mathrm{CO}_{2}$ Exchange & & \\
\hline Summer & $-43\left(45^{1} ;-27\right.$ to $\left.-59^{2}\right)$ & $5(46 ;-11$ to 21$)$ \\
Winter & $31(3 ; 1$ to 61$)$ & $31(7 ; 11$ to 51$)$ \\
Annual & $-26(27 ;-15$ to -37$)$ & $10(12 ;-27$ to 47$)$ \\
\hline $\mathrm{CH}_{4}$ Exchange & & \\
\hline Summer & $9.2(38 ; 5.4$ to 13.0$)$ & $0.8(25 ; 0.3$ to 1.4$)$ \\
Annual & $14.6(22 ; 8.5$ to 20.2$)$ & $2.3(24 ; 0.3$ to 4.3$)$ \\
\hline
\end{tabular}

\footnotetext{
${ }^{1}$ Number of site-year estimates.
}

$295 \%$ confidence interval.

\subsection{Process-based model estimates}

\subsubsection{Mean C budgets for 1990-1999 and 2000-2006}

GPP estimated by the regional applications of process-based models over the Arctic tundra region from 1990 through 1999 varies from $1755 \mathrm{TgC}^{-1}\left(191 \mathrm{~g} \mathrm{C} \mathrm{m}^{-2} \mathrm{yr}^{-1}\right)$ for LPJ-Guess WHyMe to $5295 \mathrm{Tg} \mathrm{Cyr}^{-1}\left(577 \mathrm{~g} \mathrm{C} \mathrm{m}^{-2} \mathrm{yr}^{-1}\right)$ for Orchidee (Table 5). NPP is estimated to be approximately $65 \%, 61 \%$, and $40 \%$ of GPP by LPJ-Guess WHyMe, Orchidee, and TEM6, respectively. TEM6 estimates a higher proportion of GPP allocated to autotrophic respiration because the temperature sensitivity of autotrophic respiration in the model increases with decreasing mean annual temperature (McGuire et al., 1992). RH estimates vary from $875 \mathrm{TgC} \mathrm{yr}^{-1}\left(95 \mathrm{~g} \mathrm{C} \mathrm{m}^{-2} \mathrm{yr}^{-1}\right)$ for TEM6 to $2954 \mathrm{Tg} \mathrm{Cyr}^{-1}\left(322 \mathrm{~g} \mathrm{C} \mathrm{m}^{-2} \mathrm{yr}^{-1}\right)$ for Orchidee, and $\mathrm{RH}$ is estimated to be less than NPP by each model. NEP estimates vary from $85 \mathrm{TgC}^{-1}\left(10 \mathrm{~g} \mathrm{C} \mathrm{m}^{-2} \mathrm{yr}^{-1}\right)$ for TEM6 to $255 \mathrm{Tg} \mathrm{C} \mathrm{yr}^{-1}\left(28 \mathrm{~g} \mathrm{C} \mathrm{m}^{-2} \mathrm{yr}^{-1}\right)$ for Orchidee. TEM estimates $30 \mathrm{Tg} \mathrm{C} \mathrm{yr}^{-1}$ in fire emissions, which is $20 \mathrm{Tg} \mathrm{C} \mathrm{yr}^{-1}$ more than is estimated by LPJ-Guess WHyMe. After 


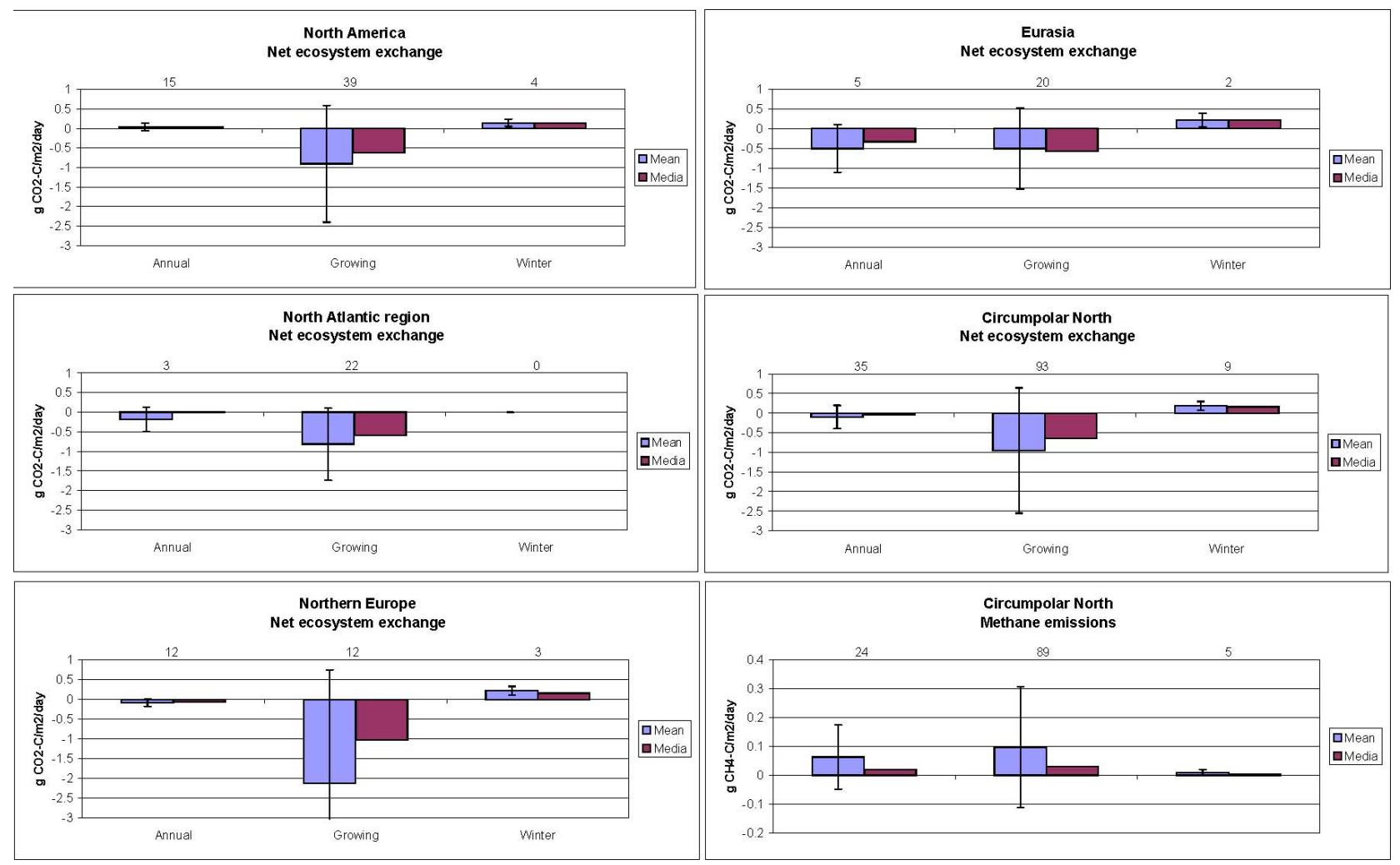

Fig. 2. A summary of the data presented in Supplement 1; the summary includes observations prior to 1990. The synthesis of observed NEE for different geographical regions is shown in the first five panels. The mean $\left(\mathrm{g} \mathrm{C} \mathrm{m}^{-2} \mathrm{day}^{-1}\right)+/-$ standard deviation and the median are shown for summer, winter, and annual analyses. The number of studies used from Supplement 1 to estimate each mean/median is shown above the bars. Methane emissions for the circumpolar North are shown in the sixth panel in a similar fashion.

accounting for fire emissions of $\mathrm{CO}_{2}$, the estimates of the net exchange of $\mathrm{CO}_{2}$ vary from $55 \mathrm{Tg} \mathrm{Cyr}^{-1}$ taken up from the atmosphere by TEM6 to $255 \mathrm{Tg} \mathrm{C} \mathrm{yr}^{-1}$ taken up by Orchidee, which is a higher range of uptake than is estimated by the global applications of process models (from neutral balance estimated by Hyland to an uptake of $188 \mathrm{Tg} \mathrm{C} \mathrm{yr}^{-1}$ by LPJ-Guess). Approximately $80 \%$ of the NEP estimated by TEM6 is lost to fire emissions, biogenic $\mathrm{CH}_{4}$ emissions, and the export of harvested products and DOC. Approximately $20 \%$ of NEP estimated by LPJ-Guess WHyMe is lost to fire and $\mathrm{CH}_{4}$ emissions. Thus, $\mathrm{NCB}$ estimated by the models varies from approximately $20 \mathrm{Tg} \mathrm{C} \mathrm{yr}^{-1}$ (TEM6) to $255 \mathrm{Tg} \mathrm{C} \mathrm{yr}^{-1}$ (Orchidee).

In comparison to the 1990 s, GPP estimated by the regional applications of process-based models over the Arctic tundra region from 2000 through 2006 is higher (from an increase of $9 \mathrm{~g} \mathrm{C} \mathrm{m}^{-2} \mathrm{yr}^{-1}$ by TEM to an increase of $38 \mathrm{~g} \mathrm{C} \mathrm{m}^{-2} \mathrm{yr}^{-1}$ by Orchidee; compare Table 6 to Table 5). The satellite-based estimate of GPP by TCF from 2000 2006 is $307 \mathrm{~g} \mathrm{C} \mathrm{m}^{-2} \mathrm{yr}^{-1}$, which is $47 \%$ and $14 \%$ higher than the estimates by LPJ-Guess WHyMe and TEM6, respectively, and $50 \%$ of the estimate by Orchidee. Similar to GPP, both NPP and RH estimates of the regional applications are higher in the 2000s compared to the 1990s. Although NEP estimates increase by 1 to $6 \mathrm{~g} \mathrm{C} \mathrm{m}^{-2} \mathrm{yr}^{-1}$ between the two decades across the models, the increase from 1990 to 2006 is significant only for the LPJ-Guess WHyMe simulation $\left(0.57 \mathrm{~g} \mathrm{C} \mathrm{m}^{-2} \mathrm{yr}^{-1} ; P=0.001\right)$. The TEM6 simulation estimates that fire emissions doubled in the 2000s compared to the 1990s. Estimates of the net uptake of $\mathrm{CO}_{2}$ increase (lower or more negative net $\mathrm{CO}_{2}-\mathrm{C}$ exchange) for both LPJ-Guess WHyMe and Orchidee in the 2000s compared to the 1990s, but decrease for TEM6. Between 1990 and 2006 both Orchidee and LPJ-Guess WHyMe estimate substantially greater net uptake of $\mathrm{CO}_{2}\left(31\right.$ and $4 \mathrm{~g} \mathrm{C} \mathrm{m}^{-2} \mathrm{yr}^{-1}$, respectively; Table 7) than TEM6 $\left(4 \mathrm{~g} \mathrm{C} \mathrm{m}^{-2} \mathrm{yr}^{-1}\right)$. Among the global models, only LPJ and SDGVM estimate less net uptake of $\mathrm{CO}_{2}$ (less negative net $\mathrm{CO}_{2}-\mathrm{C}$ exchange) in the 2000s (Table 6) compared to the 1990s (Table 5). The greatest uptake between 1990 and 2006 among the global models is simulated by LPJ-Guess $\left(23 \mathrm{~g} \mathrm{C} \mathrm{m}^{-2} \mathrm{yr}^{-1}\right)$, which is similar to the uptake estimated by LPJ-Guess WHyMe (Table 7)

To explore the importance of changing climate on the regional applications of the process-based models, we conducted additional simulations that were driven by constant climate. We estimated the effect of a changing climate on 
Table 5. Mean C budget of Arctic tundra simulated by process models for 1990-1999.

\begin{tabular}{|c|c|c|c|c|c|c|c|c|c|}
\hline Model & GPP & NPP & RH & NEP & FIREC & $\mathrm{CO}_{2}^{*}$ & $\mathrm{BIOCH}_{4}$ & OTHER & NCB \\
\hline \multicolumn{10}{|l|}{$\mathrm{gC} \mathrm{m}^{-2} \mathrm{yr}^{-1}$} \\
\hline \multicolumn{10}{|l|}{ Regional Apps. } \\
\hline LPJ-G WHyMe & 191 & 124 & 102 & 22 & 1 & -21 & 4 & - & 17 \\
\hline Orchidee & 577 & 350 & 322 & 28 & - & -28 & - & - & 28 \\
\hline TEM6 & 261 & 105 & 95 & 10 & 4 & -6 & 2 & 2 & 2 \\
\hline \multicolumn{10}{|l|}{ Global Apps. } \\
\hline CLM4C & 101 & 31 & 30 & 1 & 1 & 0 & - & - & 0 \\
\hline CLM4CN & - & - & - & 1 & - & -1 & - & - & 1 \\
\hline Hyland & 23 & 11 & 11 & 0 & - & 0 & - & - & 0 \\
\hline LPJ & 464 & 291 & 253 & 38 & 18 & -20 & - & - & 20 \\
\hline LPJ-Guess & 490 & 306 & 265 & 41 & 20 & -21 & - & - & 21 \\
\hline $\mathrm{O}-\mathrm{CN}$ & 64 & 28 & 27 & 1 & - & -1 & - & - & 1 \\
\hline SDGVM & - & - & - & 23 & 5 & -18 & - & - & 18 \\
\hline TRIFFID & 332 & 208 & 200 & 8 & - & -8 & - & - & -8 \\
\hline \multicolumn{10}{|l|}{$\operatorname{TgC~} \mathrm{yr}^{-1}$} \\
\hline \multicolumn{10}{|l|}{ Regional Apps. } \\
\hline LPJ-G WHyMe & 1755 & 1133 & 934 & 199 & 10 & -189 & 34 & - & 155 \\
\hline Orchidee & 5295 & 3209 & 2954 & 255 & - & -255 & - & - & 255 \\
\hline TEM6 & 2391 & 960 & 875 & 85 & 30 & -55 & 15 & 20 & 20 \\
\hline \multicolumn{10}{|l|}{ Global Apps. } \\
\hline CLM4C & 929 & 289 & 275 & 14 & 8 & -6 & - & - & 6 \\
\hline CLM4CN & - & - & - & 5 & - & -5 & - & - & 5 \\
\hline Hyland & 210 & 105 & 105 & 0 & - & 0 & - & - & 0 \\
\hline LPJ & 4255 & 2671 & 2323 & 348 & 169 & -179 & - & - & 179 \\
\hline LPJ-Guess & 4497 & 2804 & 2433 & 371 & 183 & -188 & - & - & 188 \\
\hline $\mathrm{O}-\mathrm{CN}$ & 585 & 256 & 252 & 4 & - & -4 & - & - & 4 \\
\hline SDGVM & - & - & - & 212 & 44 & -168 & - & - & 168 \\
\hline TRIFFID & 3053 & 1907 & 1837 & 70 & - & -70 & - & - & 70 \\
\hline
\end{tabular}

* Net $\mathrm{CO}_{2}-\mathrm{C}$ exchange, positive sign indicates source to the atmosphere and negative sign indicates tundra sink.

NPP, RH, and NEP between 1990 and 2006 by subtracting the estimates of the constant climate simulation of each model from that of the corresponding transient climate simulation. This analysis indicated that climate change between 1990 and 2006 caused NPP and RH of all three models to increase (Table 8). In comparison to TEM6, NPP was $69 \%$ and $106 \%$ more sensitive in the LPJ-Guess WHyMe and Orchidee simulations, respectively. In contrast, the RH sensitivity of LPJ-Guess WHyMe was similar to that of TEM6, while the RH sensitivity of Orchidee was $146 \%$ more sensitive than TEM6. The different sensitivities of NPP and RH caused quite different sensitivities in NEP. Climate change between 1990 and 2006 caused LPJ-Guess WHyMe NEP to increase by $8 \mathrm{~g} \mathrm{C} \mathrm{m}^{-2} \mathrm{yr}^{-1}$, TEM6 NEP to increase by $1 \mathrm{~g} \mathrm{C} \mathrm{m}^{-2} \mathrm{yr}^{-1}$, and Orchidee NEP to decrease by $4 \mathrm{~g} \mathrm{C} \mathrm{m}^{-2} \mathrm{yr}^{-1}$.

\subsubsection{Seasonal cycle and changes in the seasonal cycle}

While the shape of the seasonal cycle of NPP, RH, and NEP is similar among the regional applications of the processbased models, the amplitude of the fluxes are different (Fig. 3). All models estimate that the month of maximum production and decomposition is July, but the timing of the transition to positive NEP in the spring and to negative NEP in the autumn varies among the models. Both LPJ-Guess WHyMe and Orchidee have the same pattern of differences in monthly NEP between the 2000s and 1990s (Fig. 4), with the largest increases in July. LPJ-Guess WHyMe has relatively larger increases in May, while Orchidee has relatively larger increases in August. The summer increases of LPJGuess WHyMe and Orchidee are driven by increases in NPP that are greater than increases in RH. In contrast, TEM6 has the largest increases in September, followed by August as NPP increases in August and September are greater than 
Table 6. Mean C budget of Arctic tundra simulated by process models for 2000-2006.

\begin{tabular}{|c|c|c|c|c|c|c|c|c|c|}
\hline Model & GPP & NPP & $\mathrm{RH}$ & NEP & FIREC & $\mathrm{CO}_{2}{ }^{1}$ & $\mathrm{BIOCH}_{4}$ & OTHER & NCB \\
\hline \multicolumn{10}{|l|}{$\mathrm{gC} \mathrm{m}^{-2} \mathrm{yr}^{-1}$} \\
\hline \multicolumn{10}{|l|}{ Regional Apps. } \\
\hline LPJ-G WHyMe & 209 & 135 & 110 & 25 & 1 & -24 & 4 & - & 20 \\
\hline Orchidee & 615 & 371 & 337 & 34 & - & -34 & - & - & 34 \\
\hline TEM6 & 270 & 109 & 98 & 11 & 8 & -3 & 2 & 2 & -1 \\
\hline TCF & 307 & 181 & 183 & 2 & - & - & - & - & - \\
\hline \multicolumn{10}{|l|}{ Global Apps. } \\
\hline CLM4C & 108 & 34 & 32 & $0^{2}$ & 1 & -1 & - & - & 1 \\
\hline CLM4CN & - & - & - & 1 & - & -1 & - & - & 1 \\
\hline Hyland & 27 & 14 & 14 & 0 & - & 0 & - & - & 0 \\
\hline LPJ & 502 & 315 & 274 & $22^{2}$ & 19 & -3 & - & - & 3 \\
\hline LPJ-Guess & 562 & 349 & 305 & 44 & 20 & -24 & - & - & 24 \\
\hline $\mathrm{O}-\mathrm{CN}$ & 74 & 32 & 31 & $3^{2}$ & - & -3 & - & - & 3 \\
\hline SDGVM & - & - & - & 21 & 5 & -16 & - & - & 16 \\
\hline TRIFFID & 361 & 227 & 210 & 17 & - & -17 & - & - & 17 \\
\hline \multicolumn{10}{|l|}{$\operatorname{TgC~} \mathrm{yr}^{-1}$} \\
\hline \multicolumn{10}{|l|}{ Regional Apps. } \\
\hline LPJ-G WHyMe & 1918 & 1239 & 1009 & 230 & 9 & -221 & 37 & - & 184 \\
\hline Orchidee & 5643 & 3404 & 3092 & 312 & - & -312 & - & - & 312 \\
\hline TEM6 & 2476 & 1000 & 899 & 101 & 73 & -28 & 18 & 18 & -8 \\
\hline TCF & 2817 & 1661 & - & - & - & - & - & - & - \\
\hline \multicolumn{10}{|l|}{ Global Apps. } \\
\hline CLM4C & 994 & 314 & 296 & 18 & 9 & -9 & - & - & 9 \\
\hline CLM4CN & - & - & - & 8 & - & -8 & - & - & 8 \\
\hline Hyland & 248 & 124 & 123 & 1 & - & -1 & - & - & 1 \\
\hline LPJ & 4608 & 2887 & 2518 & 369 & 171 & -198 & - & - & 198 \\
\hline LPJ-Guess & 5160 & 3204 & 2797 & 407 & 185 & -222 & - & - & 222 \\
\hline $\mathrm{O}-\mathrm{CN}$ & 682 & 298 & 287 & 11 & - & -11 & - & - & 11 \\
\hline SDGVM & - & - & - & 193 & 47 & -146 & - & - & 146 \\
\hline TRIFFID & 3310 & 2079 & 1927 & 152 & - & -152 & - & - & 152 \\
\hline
\end{tabular}

${ }^{1} \mathrm{Net} \mathrm{CO}_{2}-\mathrm{C}$ exchange, positive sign indicates source to the atmosphere and negative sign indicates tundra sink.

2 Reported NEP does not equal reported NPP - reported RH.

increases in RH; in June and July there are similar increases in both NPP and RH. All three models indicate substantially lower NEP in October because of increases in RH when NPP is close to zero in both decades.

\subsubsection{Interannual variability}

Among the regional applications of the process-based models, Orchidee stands out as having the highest range of interannual variability in GPP, NPP, RH, and NEP (Fig. 5). Correlations are high among the models for interannual variability in the anomalies of GPP ( $R=0.73$ to 0.88 ; Fig. 5a) and RH $(R=0.81$ to 0.97 ; Fig. $5 \mathrm{c})$. The correlations for NPP anomalies (Fig. 5b) are slightly lower $(R=0.66$ to
$0.80)$, except for a low correlation between TCF and TEM6 $(R=0.23)$. In contrast, correlations among the anomalies of NEP (Fig. 5d) are poor and range from negative correlations ( $R=-0.64$ between Orchidee and TCF) to low positive correlations ( $R=0.30$ between Orchidee and TEM6).

TEM6 estimates of fire emissions are characterized by substantial interannual variability in comparison to LPJGuess WHyMe, which has little interannual variability in fire emissions (Fig. 6a); the variability is uncorrelated between the models $(R=0.07)$. LPJ-Guess estimates of biogenic $\mathrm{CH}_{4}$ emissions are correlated with those of TEM6 $(R=0.69$; Fig. $6 \mathrm{~b})$, but are characterized by more interannual variability than those of TEM6. The other flux anomalies estimated by TEM6 have less interannual variability 
Table 7. Mean C budget of Arctic tundra simulated by process models for 1990-2006.

\begin{tabular}{|c|c|c|c|c|c|c|c|c|c|}
\hline Model & GPP & NPP & RH & NEP & FIREC & $\mathrm{CO}_{2}{ }^{1}$ & $\mathrm{BIOCH}_{4}$ & OTHER & NCB \\
\hline \multicolumn{10}{|l|}{$\mathrm{gC} \mathrm{m}^{-2} \mathrm{yr}^{-1}$} \\
\hline \multicolumn{10}{|l|}{ Regional Apps. } \\
\hline LPJ-G WHyMe & 200 & 130 & 106 & 24 & 1 & -23 & 4 & - & 19 \\
\hline Orchidee & 596 & 361 & 330 & 31 & - & -31 & - & - & 31 \\
\hline TEM6 & 266 & 107 & 97 & 10 & 6 & -4 & 2 & 2 & 0 \\
\hline \multicolumn{10}{|l|}{ Global Apps. } \\
\hline CLM4C & 105 & 32 & 31 & 1 & 1 & 0 & - & - & 0 \\
\hline CLM4CN & - & - & - & 1 & - & -1 & - & - & 1 \\
\hline Hyland & 25 & 13 & 13 & 0 & - & 0 & - & - & 0 \\
\hline LPJ & 483 & 303 & 264 & $30^{2}$ & 19 & -11 & - & - & 11 \\
\hline LPJ-Guess & 526 & 328 & 285 & 43 & 20 & -23 & - & - & 23 \\
\hline $\mathrm{O}-\mathrm{CN}$ & 69 & 30 & 29 & $2^{2}$ & - & -2 & - & - & 2 \\
\hline SDGVM & - & - & - & 22 & 5 & -17 & - & - & 17 \\
\hline TRIFFID & 347 & 218 & 205 & 13 & - & -13 & - & - & 13 \\
\hline \multicolumn{10}{|l|}{$\mathrm{TgC}_{\mathrm{yr}}{ }^{-1}$} \\
\hline \multicolumn{10}{|l|}{ Regional Apps. } \\
\hline LPJ-G WHyMe & 1837 & 1186 & 972 & 214 & 9 & -205 & 35 & - & 170 \\
\hline Orchidee & 5469 & 3307 & 3023 & 284 & - & -284 & - & - & 284 \\
\hline TEM6 & 2434 & 980 & 887 & 93 & 52 & -41 & 16 & 19 & 6 \\
\hline \multicolumn{10}{|l|}{ Global Apps. } \\
\hline CLM4C & 962 & 302 & 286 & 16 & 9 & -7 & - & - & 7 \\
\hline CLM4CN & - & - & - & 8 & - & -8 & - & - & 8 \\
\hline Hyland & 229 & 115 & 114 & 1 & - & -1 & - & - & 1 \\
\hline LPJ & 4432 & 2779 & 2421 & 359 & 170 & -189 & - & - & 189 \\
\hline LPJ-Guess & 4829 & 3004 & 2615 & 389 & 184 & -205 & - & - & 205 \\
\hline $\mathrm{O}-\mathrm{CN}$ & 634 & 277 & 270 & 7 & - & -7 & - & - & 7 \\
\hline SDGVM & - & - & - & 203 & 46 & -157 & - & - & 157 \\
\hline TRIFFID & 3182 & 1993 & 1882 & 111 & - & -111 & - & - & 111 \\
\hline
\end{tabular}

\footnotetext{
${ }^{1} \mathrm{Net} \mathrm{CO}_{2}-\mathrm{C}$ exchange, positive sign indicates source to the atmosphere and negative sign indicates tundra sink.

2 Reported NEP does not equal reported NPP - reported RH.
}

$\left(\sim 0.25 \mathrm{~g} \mathrm{C} \mathrm{m}^{-2}\right.$; Fig. $\left.6 \mathrm{c}\right)$ than fire emissions $\left(\sim 16 \mathrm{~g} \mathrm{C} \mathrm{m}^{-2}\right.$; Fig. 6a) and bioigenic $\mathrm{CH}_{4}$ emissions $\left(\sim 0.5 \mathrm{~g} \mathrm{C} \mathrm{m}^{-2}\right.$; Fig. 6b). In general, the correlations among the models for interannual variability in NCB (Fig. 6d) are similar to those for NEP (Fig. 6d), except that all of the correlations are weaker between TEM6 and the other models. This suggests that fire emissions, biogenic $\mathrm{CH}_{4}$ emissions, and other export fluxes are important to consider in evaluating interannual variability in carbon storage of Arctic tundra.

\subsection{Atmospheric inversion estimates}

We analyzed the net exchange of $\mathrm{CO}_{2}$ (i.e., NEE) between Arctic tundra and the atmosphere estimated by inversions for 1990-1999 and 2000-2006 (Table 9). Among the three models that made estimates between 1990 and 1999, the mean annual exchange ranged from a source of
$140 \mathrm{Tg} \mathrm{C} \mathrm{yr}^{-1}\left(15 \mathrm{~g} \mathrm{C} \mathrm{m}^{-2} \mathrm{yr}^{-1}\right)$ to a sink of $321 \mathrm{Tg} \mathrm{C} \mathrm{yr}^{-1}$ ( $35 \mathrm{~g} \mathrm{C} \mathrm{m}^{-2} \mathrm{yr}^{-1}$ ). In comparison to the 1990-1999 time period, the range among the eight models that made estimates for 2000-2006 is wider and ranges from a source of $206 \mathrm{Tg} \mathrm{C} \mathrm{yr}^{-1}\left(22 \mathrm{~g} \mathrm{C} \mathrm{m}^{-2} \mathrm{yr}^{-1}\right)$ to a sink of $439 \mathrm{Tg} \mathrm{C} \mathrm{yr}^{-1}$ (48 $\mathrm{g} \mathrm{C} \mathrm{m}^{-2} \mathrm{yr}^{-1}$ ).

The shape of the mean seasonal cycle of NEE between 2000 and 2006 is generally similar among the inversions (Fig. 7). All models indicate that the maximum NEE occurs in July, but the number of months with negative NEE varies among the models between two (C13_MATCH_rayner) and four (LSCE_an_v2.1). Among the inversion models, the NEE estimates of individual months are generally within $10 \mathrm{~g} \mathrm{C} \mathrm{m}^{-2}$ except for LSCE_an_v2.1, which estimates higher releases of $\mathrm{CO}_{2}$ to the atmosphere 
Table 8. Inferred climate effect of NPP, RH, and NEP for 19902006 as the difference between simulations of the regional applications of process models driven by transient climate and constant climate.

\begin{tabular}{lccc}
\hline Model & $\begin{array}{c}\text { Transient } \\
\text { Climate }\end{array}$ & $\begin{array}{c}\text { Constant } \\
\text { Climate }\end{array}$ & $\begin{array}{c}\text { Inferred } \\
\text { Climate } \\
\text { Effect }\end{array}$ \\
\hline $\mathrm{NPP}\left(\mathrm{g} \mathrm{C} \mathrm{m}^{-2} \mathrm{yr}^{-1}\right)$ & & & \\
\hline LPJ-Guess WHyMe & 128 & 101 & 27 \\
Orchidee & 359 & 326 & 33 \\
TEM6 & 106 & 90 & 16 \\
\hline RH $\left(\mathrm{g} \mathrm{C} \mathrm{m}^{-2} \mathrm{yr}^{-1}\right)$ & & & \\
\hline LPJ-Guess WHyMe & 105 & 86 & 19 \\
Orchidee & 328 & 291 & 37 \\
TEM6 & 96 & 81 & 15 \\
\hline NEP $\left(\mathrm{g} \mathrm{C} \mathrm{m}^{-2} \mathrm{yr}^{-1}\right)$ & & & \\
\hline LPJ-Guess WHyMe & 23 & 15 & 8 \\
Orchidee & 31 & 35 & -4 \\
TEM6 & 10 & 9 & 1 \\
\hline
\end{tabular}

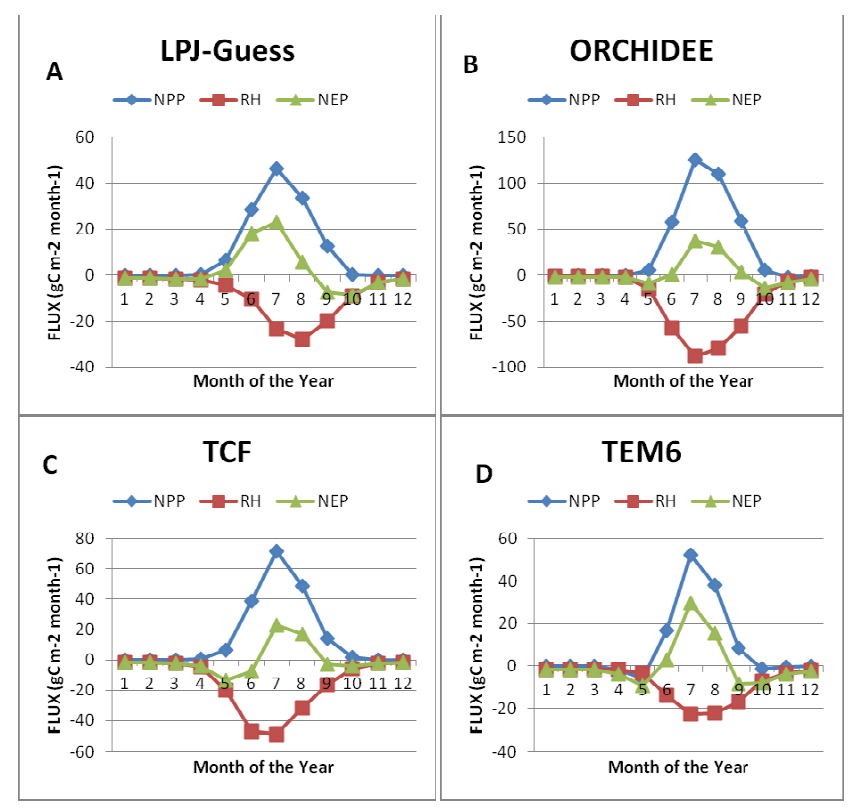

Fig. 3. Mean monthly fluxes of gross primary production (GPP), net primary production (NPP), heterotrophic respiration (RH), and net ecosystem production (NEP) simulated by LPJ-Guess WHyMe (Panel A), Orchidee (Panel B), and TEM6 (Panel D) between 1990 and 2006 and by TCF (Panel C) between 2000 and 2009.

than the other models in April and May and higher uptake of $\mathrm{CO}_{2}$ in July, August, and September.

Among the inversion models, interannual variability is smallest for LSCE_an_v2.1 (standard deviation of NEE anomalies $=2.1 \mathrm{~g} \mathrm{C} \mathrm{m}^{-2} \mathrm{yr}^{-1}$ ) and largest for rigc_patra

\section{Decadal Difference in Monthly NEP}

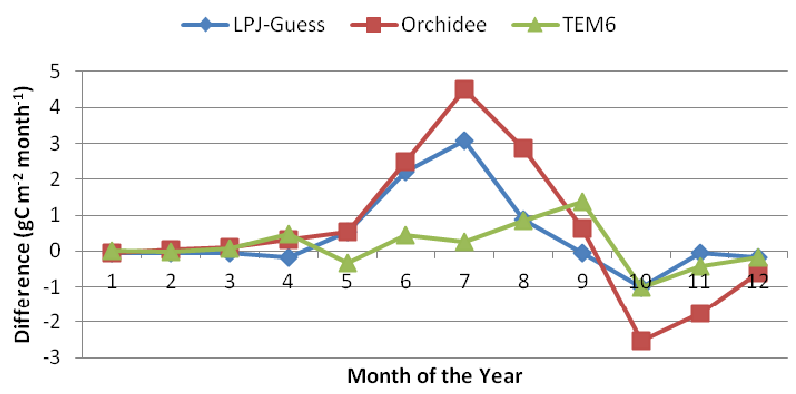

Fig. 4. Difference in mean monthly NEP between the 2000s (20002006) and the 1990s (1990-1999) for LPJ-Guess WHyMe, Orchidee, and TEM6.

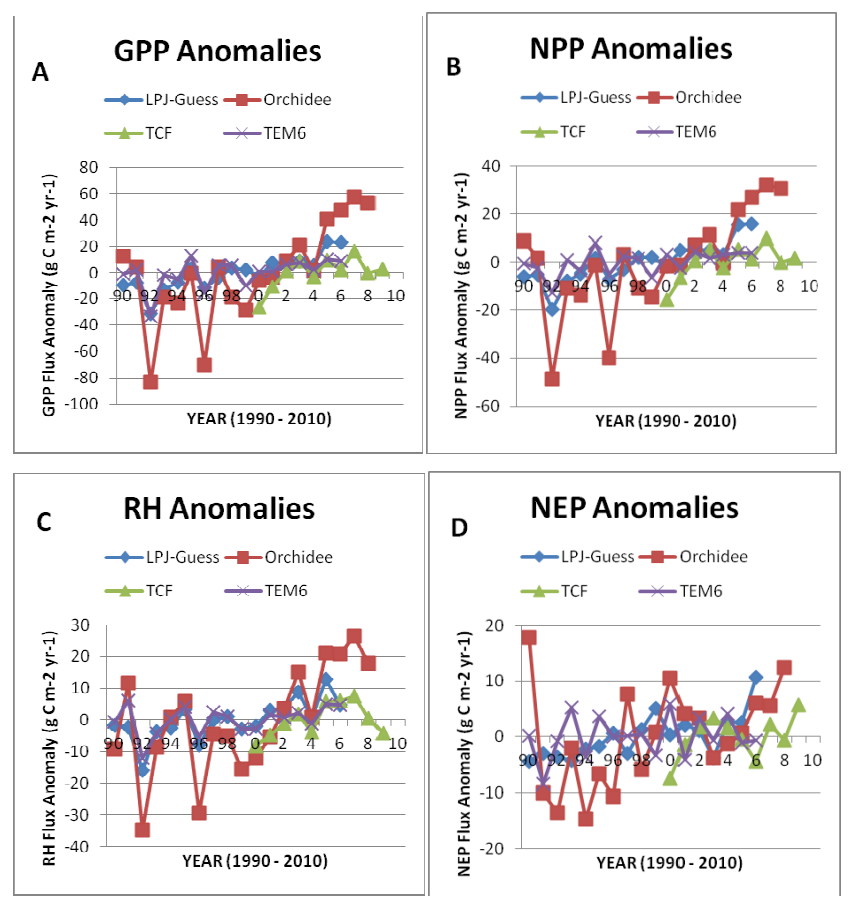

Fig. 5. Comparisons among LPJ-Guess WHyMe, Orchidee, TCF, and TEM of inter-annual variability between 1990 and 2010 for anomalies of gross primary production (GPP, Panel A), net primary production (NPP, Panel B), heterotrophic respiration (NPP, Panel C), and net ecosystem production (NEP, Panel D).

(standard deviation $\left.=13.1 \mathrm{~g} \mathrm{C} \mathrm{m}^{-2} \mathrm{yr}^{-1}\right)($ Fig. 8). Similar to the correlations of interannual variability in NEP anomalies among the process-based models, the correlations of interannual variability in NEE anomalies among the inversion models is poor with a mean correlation of 0.03 ; correlations range between -0.38 (between CTRACKER_EU and C13_CCAM_law) to +0.99 (between CTRACKER_US and LSCE_an_v2.1). 
Table 9. Mean annual net $\mathrm{CO}_{2}-\mathrm{C}$ exchange estimates of inversion models of Arctic tundra for the time periods 1990-1999 and 2000-2006.

\begin{tabular}{lrrrrrr}
\hline Model & $\begin{array}{r}1990-1999 \\
\mathrm{Tg} \mathrm{C} \mathrm{yr}^{-1}\end{array}$ & $\begin{array}{r}2000-2006 \\
\mathrm{TgC} \mathrm{yr}^{-1}\end{array}$ & $\begin{array}{r}1990-2006 \\
\mathrm{Tg} \mathrm{C} \mathrm{yr}^{-1}\end{array}$ & $\begin{array}{r}1990-1999 \\
\mathrm{gC} \mathrm{m}^{-2} \mathrm{yr}^{-1}\end{array}$ & $\begin{array}{r}2000-2006 \\
\mathrm{~g} \mathrm{C} \mathrm{m}^{-2} \mathrm{yr}^{-1}\end{array}$ & $\begin{array}{r}1990-2006 \\
\mathrm{~g} \mathrm{C} \mathrm{m}^{-2} \mathrm{yr}^{-1}\end{array}$ \\
\hline C13_CCAM_law & - & 243 & & - & 26 & \\
C13_MATCH_rayner & - & -283 & & - & -31 & \\
JENA_56_v3.3 & - & -117 & & - & -13 & \\
JMA_2010 & -321 & -341 & -331 & -35 & -37 & -36 \\
LSCE_an_v2.1 & - & -124 & & - & -14 & \\
LSCE_var_v1.0 & 140 & 206 & 173 & 15 & 22 & 19 \\
NICAM_niwa_woaia & -178 & -80 & -129 & -19 & -9 & \\
rigc_Patra & - & -439 & & - & -48 & -14 \\
\hline
\end{tabular}
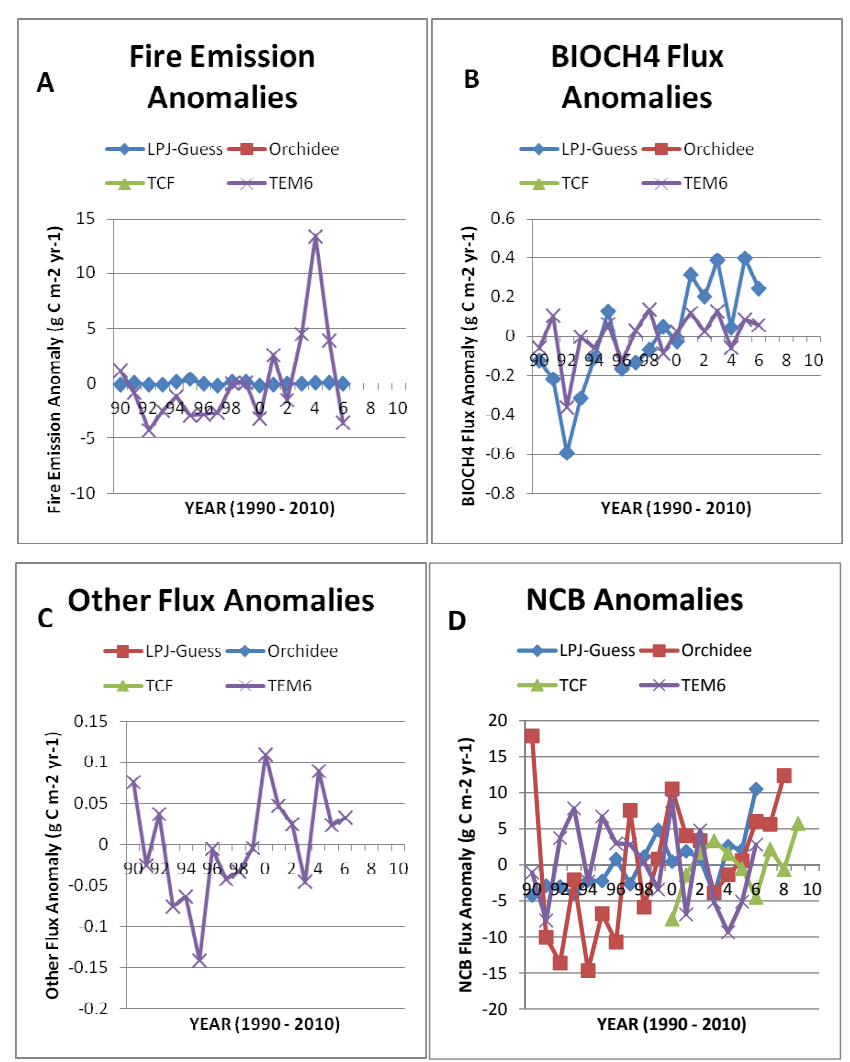

Fig. 6. Comparisons among LPJ-Guess WHyMe, Orchidee, TCF, and TEM of inter-annual variability between 1990 and 2010 for anomalies of fire emissions (Panel A), biogenic $\mathrm{CH}_{4}$ emissions (Panel B), Other fluxes (harvest and DOC exports, Panel C), and net carbon balance (NCB, Panel D).

\section{Discussion}

The changing $\mathrm{C}$ balance of Arctic tundra has been an issue of concern for several decades (Billings et al., 1983; Oechel et al., 1993; McGuire et al., 2000, 2009, 2010; Chapin et al., 2000; Sitch et al., 2007; Hayes et al., 2011). It has been hypothesized that tundra will become a source of $\mathrm{C}$ to the atmosphere because of $\mathrm{C}$ emissions associated with the warming

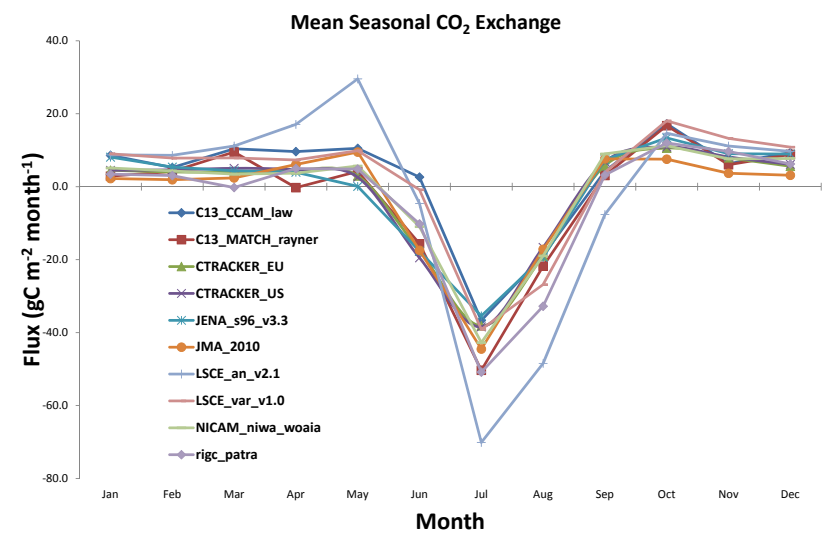

Fig. 7. Comparison among inversion model estimates of the mean net monthly exchange of $\mathrm{CO}_{2}$ between Arctic tundra and the atmosphere.

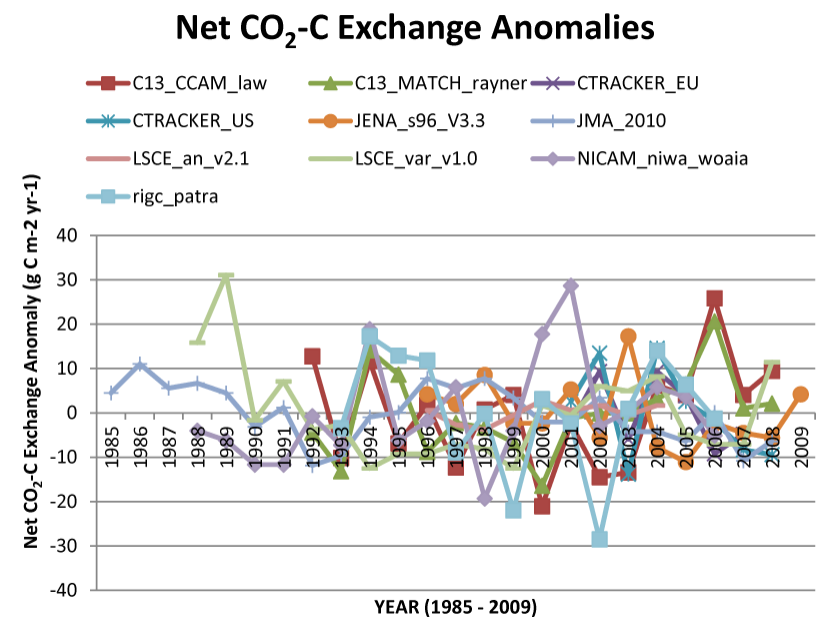

Fig. 8. Comparison among inversion model estimates of the interannual variability between 1985 and 2009 for anomalies of the net annual exchange of $\mathrm{CO}_{2}$ between arctic tundra and the atmosphere.

of soil organic matter in the active layer as well as the exposure of previously frozen $\mathrm{C}$ to decomposition as the active layer deepens. Some recent model applications that consider 
soil C stocks at depth in high latitudes and the exposure of those stocks to decomposition upon permafrost thaw indicate that northern terrestrial ecosystems will release soil C to the atmosphere (Koven et al., 2011; Schaefer et al., 2011; Schneider von Deimling et al., 2012). It has also been hypothesized that tundra could become a sink for atmospheric $\mathrm{CO}_{2}$ if $\mathrm{N}$-limited plants in tundra regions take up a substantial proportion of $\mathrm{N}$ that is released by enhanced decomposition (Shaver et al., 1992). Some coupled climate-carbon model simulations predict that the northern high latitudes will serve as a substantial land carbon sink during the 21 st century because both climate warming and elevated global $\left[\mathrm{CO}_{2}\right]$ favor increased productivity and $\mathrm{CO}_{2}$ uptake in the region (Friedlingstein et al., 2006; Qian et al., 2010; Sitch et al., 2008). Whether tundra becomes a source or a sink of atmospheric $\mathrm{CO}_{2}$ in response to warming is an important scientific issue to resolve, as substantial source activity could compromise efforts to mitigate the increase of greenhouse gases in the atmosphere. Changes in $\mathrm{CH}_{4}$ emissions are also important, because of the high global warming potential of $\mathrm{CH}_{4}$. In terms of climate forcing, increasing $\mathrm{CH}_{4}$ emissions could offset the effects of a $\mathrm{CO}_{2}$ sink, or enhance the effects of a $\mathrm{CO}_{2}$ source. In this study, we attempt to shed some light on these issues by analyzing the $\mathrm{C}$ balance of Arctic tundra through a synthetic comparison among estimates of $\mathrm{CO}_{2}$ and $\mathrm{CH}_{4}$ fluxes based on observations, regional and global applications of process-based models, and inversion models. We focused our comparison on the mean $\mathrm{CO}_{2}$ and $\mathrm{CH}_{4}$ budgets for the time periods 1990-1999 and 2000-2006, on aspects of the seasonal cycle of $\mathrm{CO}_{2}$ exchange, and on interannual variability of $\mathrm{CO}_{2}$ exchange.

\subsection{Mean C budgets for the 1990s and 2000s}

Table 10 compares the mean net exchanges of $\mathrm{CO}_{2}-\mathrm{C}$ and $\mathrm{CH}_{4}$ - $\mathrm{C}$ from Arctic tundra to the atmosphere among observations, process-based models, and inversion models (see Supplement 3 for documentation of the estimates reported in Table 10). Syntheses of the compilation of flux observations and of inversion model results for Arctic tundra indicate that the annual exchange of $\mathrm{CO}_{2}$ between Arctic tundra and the atmosphere has large uncertainties that cannot be distinguished from neutral balance. The synthesis of process-based model simulations indicate that Arctic tundra has been acting as a sink for atmospheric $\mathrm{CO}_{2}$, but based on the uncertainty estimates it is not clear if Arctic tundra acted as a weak or a strong sink. In comparison to the global process-based models, the regional process-based models indicate that Arctic tundra acted as a stronger sink.

Analysis of the CRU-NCEP data sets indicates that the region was $0.6^{\circ} \mathrm{C}$ warmer in the 2000 s compared to the 1990 s. Most of the warming was in the autumn and winter $\left(1.1^{\circ} \mathrm{C}\right.$ warmer) followed by summer $\left(0.3^{\circ} \mathrm{C}\right.$ warmer $)$, and little difference in the spring. The pattern of warmer autumns, winters, and summers in the 2000s occurred in all of the subre- gions except North America in which the mean summer temperature was not different between the two decades. It is notable that the central estimates of the observations, processbased models, and inversion models each identify stronger $\mathrm{CO}_{2}$ sinks in the warmer 2000s compared with the 1990s. A stronger sink in the 2000s compared to the 1990s suggests that the efficiency of the tundra $\mathrm{CO}_{2}$ sink is not currently weakening; a common response of process-based models to warming in this region is that NPP increases faster in response to warming than RH (Sitch et al., 2007).

The largest changes in central estimates between the 1990s and 2000s are for those of the observations and the inversion models, and there is more convergence among the central estimates in the 2000s than in the 1990s. The large changes between decades for the observations and inversion models might reflect biases in the 1990s since the diversity of flux observations, and the number of $\mathrm{CO}_{2}$ concentration measuring stations and inversion model applications were fewer than in the 2000s. The only mean source activity is that suggested by the observations in the 1990s. In particular, the source strength of the observations in North America in the 1990s is driving the overall source estimate for Arctic tundra in the 1990s. It is possible that sampling of observations in the 1990s was biased toward dry tundra, which tends to act as a source for $\mathrm{C}$ in the observations in both the 1990s and 2000s.

In general, the regional process-based model applications predict stronger sinks than the suite of global applications of DGVMs. This is primarily due to the response of Orchidee, which has the highest NPP and NEE among the 11 models. It is notable that NPP and the sink strength of O-CN is much less than that of Orchidee, which might reflect the role of $\mathrm{N}$ in limiting productivity in O-CN. Although the sink strength of the central estimates of both regional and global processbased model applications increase from the 1990s and 2000s, 5 of the 11 process-based models show either no change or a weaker sink between decades (TEM6, CLM4CN, Hyland, LPJ, and SDGVM). Detailed analysis of one of the model applications (TEM6) suggests that tundra became a weaker sink from the 1970s through the 2000s because of the effects of climate on net ecosystem carbon balance (McGuire et al., 2010). The constant climate experiments we conducted with the regional model applications suggests that warming increases both NPP and RH in all three models, but that the relative responses of NPP and RH to warming are different among the models. This analysis indicates that the processbased models do not agree on the relative responses of NPP and RH to climate change, and that this uncertainty in the responses of NPP and RH in these models is the major limitation in the application of process-based models to assess whether Arctic tundra will act as a positive or negative feedback to climate change.

Our analysis of $\mathrm{CH}_{4}$ responses between decades is limited to comparison between the observations and the regional model applications (Table 10). There is substantial 
Table 10. Comparison of estimates of mean net $\mathrm{CO}_{2}-\mathrm{C}$ and $\mathrm{CH}_{4}-\mathrm{C}$ exchange from arctic tundra to the atmosphere $\left(\mathrm{Tg} \mathrm{C} \mathrm{yr}^{-1}\right)$ among observations, process-based models, and inversion models.

\begin{tabular}{|c|c|c|c|c|}
\hline Time Period & Observations & $\begin{array}{l}\text { Regional Process- } \\
\text { Based Models }\end{array}$ & $\begin{array}{l}\text { Global Process- } \\
\text { Based Models }\end{array}$ & Inversion Models \\
\hline \multicolumn{5}{|l|}{$\mathrm{CO}_{2}$ Exchange } \\
\hline \multicolumn{5}{|l|}{ 1990-1999 } \\
\hline $\begin{array}{l}\text { Central Estimate } \\
\text { Uncertainty }\end{array}$ & $\begin{array}{l}138 \\
-102 \text { to } 378\end{array}$ & $\begin{array}{l}-166 \\
-255 \text { to }-55\end{array}$ & $\begin{array}{l}-78 \\
-188 \text { to } 0\end{array}$ & $\begin{array}{l}-13 \\
-321 \text { to } 140\end{array}$ \\
\hline \multicolumn{5}{|l|}{$2000-2006^{*}$} \\
\hline $\begin{array}{l}\text { Central Estimate } \\
\text { Uncertainty }\end{array}$ & $\begin{array}{l}-202 \\
-628 \text { to } 224\end{array}$ & $\begin{array}{l}-187 \\
-312 \text { to }-28\end{array}$ & $\begin{array}{l}-93 \\
-222 \text { to }-1\end{array}$ & $\begin{array}{l}-117 \\
-439 \text { to } 243\end{array}$ \\
\hline \multicolumn{5}{|l|}{ 1990-2006* } \\
\hline $\begin{array}{l}\text { Central Estimate } \\
\text { Uncertainty }\end{array}$ & $\begin{array}{l}-103 \\
-297 \text { to } 89\end{array}$ & $\begin{array}{l}-177 \\
-284 \text { to }-41\end{array}$ & $\begin{array}{l}-86 \\
-205 \text { to }-1\end{array}$ & $\begin{array}{l}-96 \\
-331 \text { to } 173\end{array}$ \\
\hline \multicolumn{5}{|l|}{$\mathrm{CH}_{4}$ Exchange } \\
\hline \multicolumn{5}{|l|}{ 1990-1999 } \\
\hline $\begin{array}{l}\text { Central Estimate } \\
\text { Uncertainty }\end{array}$ & $\begin{array}{l}10 \\
-1 \text { to } 22\end{array}$ & $\begin{array}{l}25 \\
15 \text { to } 34\end{array}$ & - & - \\
\hline \multicolumn{5}{|l|}{$2000-2006^{*}$} \\
\hline $\begin{array}{l}\text { Central Estimate } \\
\text { Uncertainty }\end{array}$ & $\begin{array}{l}20 \\
-11 \text { to } 51\end{array}$ & $\begin{array}{l}28 \\
18 \text { to } 37 \\
\end{array}$ & - & - \\
\hline \multicolumn{5}{|l|}{ 1990-2006* } \\
\hline $\begin{array}{l}\text { Central Estimate } \\
\text { Uncertainty }\end{array}$ & $\begin{array}{l}11 \\
0 \text { to } 22\end{array}$ & $\begin{array}{l}26 \\
16 \text { to } 35\end{array}$ & - & - \\
\hline
\end{tabular}

uncertainty in the 2000s $\mathrm{CH}_{4}$ flux observation-based estimate. Because of big differences in estimates of $\mathrm{CH}_{4}$ fluxes between wet and dry/mesic tundra (Table 4), uncertainties could be reduced by adequately sampling $\mathrm{CH}_{4}$ exchange between these two types of tundra within each of the subregions that we considered in scaling the $\mathrm{CH}_{4}$ observations. The synthesis of observations produces central estimates in the 1990s $\left(10 \mathrm{Tg} \mathrm{CH}_{4}-\mathrm{C} \mathrm{yr}^{-1}\right)$ and $2000 \mathrm{~s}\left(20 \mathrm{Tg} \mathrm{CH}_{4}-\mathrm{C} \mathrm{yr}^{-1}\right)$ that are consistent with the range of uncertainty ( 23 to $75 \mathrm{Tg} \mathrm{CH}_{4}$ $\mathrm{C} \mathrm{yr}^{-1}$ ) among observation-based and process-model estimates (McGuire et al., 2009) for northern high latitude terrestrial regions that include boreal forest in addition to tundra. The central estimates in Table 10 are also consistent with the range of uncertainty (11 to $38 \mathrm{Tg} \mathrm{CH}_{4}-\mathrm{C} \mathrm{yr}^{-1}$ ) among $\mathrm{CH}_{4}$ inversion models for northern high latitudes (McGuire et al., 2009). Similarly, the range of uncertainty of $\mathrm{CH}_{4}$ exchange estimated by LPJ-Guess WHyMe and TEM6 are within the ranges of uncertainty for both the bottom-up (based on observations and process-based models) and top-down (based on inversion models) reported by McGuire et al. (2009).
The central estimates of the observations suggest that $\mathrm{CH}_{4}$ emissions have increased more than $100 \%$ from the $1990 \mathrm{~s}$ to the 2000s, while the applications of LPJ-Guess WHyMe and TEM6 suggest that $\mathrm{CH}_{4}$ emissions have only increased $\sim 10-20 \%$ from the 1990 s to the 2000s. Previous analyses with TEM6 suggest that increasing temperature is the most important climate variable in the response of $\mathrm{CH}_{4}$ emissions to climate change (Zhuang et al., 2007; McGuire et al., 2010). However, it is important to recognize that there are substantial uncertainties and challenges in accurately modeling the response of $\mathrm{CH}_{4}$ emissions to climate change in the Arctic (Ringeval et al., 2010; Petrescu et al., 2010).

\subsection{Seasonal cycle and changes in the seasonal cycle}

The sink strength of Arctic tundra for $\mathrm{CO}_{2}$ could increase between decades because of more net $\mathrm{CO}_{2}$ uptake during the middle of the growing season or because of greater net uptake of $\mathrm{CO}_{2}$ at either the start or end of the growing season. In general, the pattern of mean seasonal cycle NEP of the regional model applications is consistent with the pattern of 
mean seasonal cycle NEE of the inversion models. All applications identify that the greatest $\mathrm{CO}_{2}$ uptake occurs in July, but there are differences among both the regional model applications and inversions about the length of the net uptake period. Our analysis of the seasonal exchange of $\mathrm{CO}_{2}$ of the regional model applications indicates that NPP of LPJ-Guess WHyMe, Orchidee, and TEM6 increased during the growing season in the 2000s compared to the 1990s. This is consistent with a number of remote sensing studies that have concluded that the Arctic tundra has become more productive during the last several decades (Nemani et al., 2003; Zhang et al., 2008; Beck and Goetz, 2011; Goetz et al., 2011) in association with warmer summers (Piao et al., 2011). However, the models show different patterns in the response of NEP between decades. Both LPJ-Guess WHyMe and Orchidee show strong patterns of mid-growing season because NPP is more responsive than $\mathrm{RH}$ to the higher growing season temperatures of the 2000s. In contrast, TEM6 has stronger NEP increases late in the growing season. A number of studies have concluded that the growing season in northern high latitude regions has increased in recent decades (McDonald et al., 2004; Euskirchen et al., 2006; Parmesan, 2007; Karlsen et al., 2009; Piao et al., 2011), although the increase varies both spatially and temporally. The TEM6 late season NEP response is consistent with a recent analysis for boreal Eurasia that suggests that the springtime extension of the growing season has stalled from 1997-2006 while the fall season has continued to lengthen and warm (Piao et al., 2011). The pattern of lower October NEP between decades among all three models is consistent with the analysis of Piao et al. (2008), which concludes that warmer and longer falls lead to greater $\mathrm{CO}_{2}$ release in northern terrestrial ecosystems (see also Parmentier et al., 2011).

\subsection{Interannual variability}

Our analysis of inter-annual NEP anomalies among the regional model applications and of inter-annual NEE anomalies among the inversion models indicates that there is little agreement among the models on the pattern of interannual exchanges of $\mathrm{CO}_{2}$ between Arctic tundra and the atmosphere. Although different inversions generally agree on the pattern inter-annual variability of regional NEE (Gurney et al., 2008), this is not the case for the Arctic tundra region and suggests that the inversions are not well constrained in this region. The regional applications of the process-models generally agree on patterns of inter-annual variability for GPP, NPP, and RH. The interannual patterns of GPP for LPJGuess WhyMe, Orchidee, and TEM6 are consistent with the satellite-based inter-annual variability of TCF, but the interannual variability of TEM6 NPP is not well correlated with that of TCF. Clearly, differences between GPP / NPP and RH need to be better constrained for the models to improve estimates of inter-annual variability.

\subsection{Best estimates of carbon balance from 1990-2009}

For the arctic tundra region, the use of observations, processbased models, and inversion models each have shortcomings with respect to estimating the net exchanges of $\mathrm{CO}_{2}$ and $\mathrm{CH}_{4}$ with the atmosphere in the 1990s and 2000s. Problems with observations include small sample size in comparison to the area being considered, biases in tundra types sampled in both space and time, different sampling technologies among the samples, and changes in sampling technology through time. Process-models have uncertainties with respect to conceptualization, formulation, and parameterization issues. Inversion models are not well constrained for the tundra regions. Given the shortcomings of these approaches, we decided to weight them equally in making estimates of net $\mathrm{CO}_{2}$ and $\mathrm{CH}_{4}$ exchange with the atmosphere for the time period from 1990-2009. For estimating $\mathrm{CO}_{2}$ exchange, we first averaged the regional and global process-based model central estimates and high and low estimates of uncertainty for the 1990-2006 period in Table 10 and then average those estimates with the corresponding estimates for the observations and inversion models. This procedure results in an estimate of the net $\mathrm{CO}_{2}-\mathrm{C}$ exchange of $\mathrm{CO}_{2}$ between the atmosphere and tundra ecosystems of a $110 \mathrm{Tg} \mathrm{C} \mathrm{yr}^{-1}$ sink with an uncertainty range between a sink of $291 \mathrm{Tg} \mathrm{C} \mathrm{yr}^{-1}$ and a source of $80 \mathrm{Tg} \mathrm{C} \mathrm{yr}^{-1}$. For estimating $\mathrm{CH}_{4}$ exchange, we averaged the central and the high and low estimates of uncertainty for the 1990-2006 period in Table 10 between the observations and the regional process-based models. This procedure results in an estimate of net $\mathrm{CH}_{4}-\mathrm{C}$ exchange between the atmosphere and tundra ecosystems of a source of $19 \mathrm{Tg} \mathrm{Cyr}^{-1}$ with an uncertainty range between sources of 8 and $29 \mathrm{TgC}^{-1}$.

\section{Conclusions}

The syntheses of the compilation of flux observations and of inversion model results for Arctic tundra in this study indicate that the annual exchange of $\mathrm{CO}_{2}$ between Arctic tundra and the atmosphere has large uncertainties that cannot be distinguished from neutral balance in the 1990s and 2000s. In contrast, the synthesis of process-based model simulations indicate that Arctic tundra acted as a sink for atmospheric $\mathrm{CO}_{2}$ in recent decades, but based on the uncertainty estimates it is not clear if Arctic tundra acted as a weak or a strong sink. Our analyses suggest that both the $\mathrm{CO}_{2}$ sink strength and the $\mathrm{CH}_{4}$ emissions of Arctic tundra have increased in recent decades. However, the analyses we conducted in this study indicate that responses of the seasonal exchange of $\mathrm{CO}_{2}$ between decades and the interannual variability in $\mathrm{CO}_{2}$ exchange of process-based models are not consistent. Although the regional models generally agree on patterns of inter-annual variability in production and decomposition, the constant climate experiments we conducted with the regional models indicates that the relative sensitivity of production and decomposition to climate change are different among 
the models. Thus, it is clearly important to reduce uncertainties in the observations, process-based models, and inversions in order to better understand the degree to which Arctic tundra is influencing atmospheric $\mathrm{CO}_{2}$ and $\mathrm{CH}_{4}$ concentrations. As inversion models are currently poorly constrained for making estimates of $\mathrm{CO}_{2}$ exchange for Arctic tundra, there is a need to identify and place additional atmospheric $\mathrm{CO}_{2}$ monitoring stations in a strategic fashion for better constraining inversion models. The availability and technology of ground-based observations in Arctic tundra are improving, particularly through the implementation of the Arctic Observing Network that has been ongoing since the beginning of the International Polar Year in 2007 (Sörlin and Danell, 2008). However, it is important to improve the network so that observations can be effectively stratified into those for dry/mesic tundra vs. wet tundra so that regional estimates based on ground-based observations can be improved and uncertainties reduced. More importantly, observation networks need to be designed so that the observations can ultimately be synthesized to understand how and why the net annual and seasonal exchanges of $\mathrm{CO}_{2}$ and $\mathrm{CH}_{4}$ are changing in response to climate variability and change in different tundra types that span hydrological variability. Also, the effects of disturbances such as fire and thermokarst on the exchange of $\mathrm{CO}_{2}$ and $\mathrm{CH}_{4}$ are not well represented in observation networks. Information from enhanced observation networks needs to be effectively transferred into process-based models to improve the simulation of $\mathrm{CO}_{2}$ and $\mathrm{CH}_{4}$ exchange so that process-based models can more reliably assess whether Arctic tundra will act as to amplify or mitigate global climate change. The effective transfer of this information requires better coordination, integration, and synthesis among measurement groups and between measurement and modeling groups.

\section{Supplementary material related to this article is available online at: http://www.biogeosciences.net/9/ 3185/2012/bg-9-3185-2012-supplement.pdf.}

Acknowledgements. Support for this study was provided by the National Science Foundation, the US Geological Survey, the US Fish and Wildlife Service, the US Department of Energy Office of Science (Biological and Environmental Research), the US National Aeronautics and Space Administration Terrestrial Ecology program, the European Union RTN GREENCYCLES II network, the Swedish Research Council VR and FORMAS, the Greenland Climate Research Center, the Mistra Swedish Research Programme for Climate, Impacts and Adaptation, the Lund University research programme Modelling the Regional and Global Earth System, the European Union 6th Framework CARBO-North project, and the Lund University Centre for Studies of Carbon Cycle and Climate Interactions. The data for the global process-model simulations was provided by the Trendy multi-model evaluation project (http://dgvm.ceh.ac.uk), as part of the Global Carbon Project.

Edited by: J. Canadell

\section{References}

Asner, G. P., Scurlock, M. O., and Hicke, J. A.: Global synthesis of leaf area index observations: Implications for ecological and remote sensing studies, Global Ecol. Biogeogr., 12, 191-205, 2003.

Beck, P. S. A. and Goetz, S. J.: Satellite observations of high northern latitude vegetation productivity changes between 1982 and 2008: ecological variability and regional differences, Environ. Res. Lett., 6, 045501, doi:10.1088/1748-9326/6/4/045501, 2011.

Billings, W. D., Loken, J. O., Mortensen, D. A., and Peterson, K. M.: Increasing atmospheric carbon dioxide: possible effects on arctic tundra, Oecologia, 58, 286-289, 1983.

Bonan, G. B. and Levis, S.: Quantifying carbon-nitrogen feedbacks in the Community Land Model (CLM4), Geophys. Res. Lett., 37, L07401, doi:10.1029/2010GL042430, 2010.

Callaghan, T. V., Björn, L. O., Chapin, F. S. III, Chernov, Y., Christensen, T. R., Huntley, B., Ims, R. A., Johansson, M., Jolly, D., Jonasson, S., Matveyeva, N., Oechel, W. C., Panikov, N., Shaver, G. R., Elster, J., Henttonen, H., Jónsdóttir, I. S., Laine, K., Schaphoff, S., Sitch, S., Taulavuori, E., Taulavuori, K., and Zöckler, C.: Arctic tundra and polar desert ecosystems, in: Arctic climate impact assessment (ACIA), 243-352, Cambridge University Press, Cambridge, UK, 2005.

Canadell, J. G., Ciais, P., Gurney, K., Le Quere, C., Piao, S., Raupach, M. R., and Sabine, C. L.: An international effort to quantify regional carbon fluxes, Eos, 92, 81-82, 2011.

Chapin III, F. S., McGuire, A. D., Randerson, J., Pielke Sr., R., Baldocchi, D., Hobbie, S. E., Roulet, N., Eugster, W., Kasischke, E., Rastetter, E. B., Zimov, S. A., Oechel, W. C., and Running, S. W.: Feedbacks from arctic and boreal ecosystems to climate, Global Change Biol., 6, S211-S223, 2000.

Chapin III, F. S., Randerson, J. T., McGuire, A. D., Foley, J. A., and Field, C. B.: Changing feedbacks in the climate-biosphere system, Front. Ecol. Environ., 6, 313-320, doi:10.1890/080005, 2008.

Cox, P. M.: Description of the "TRIFFID" dynamic global vegetation model, Hadley Centre Technical Note 24, 2001.

Euskirchen, E. S., McGuire, A. D., Kicklighter, D. W., Zhuang, Q., Clein, J. S., Dargaville, R. J., Dye, D. G., Kimball, J. S., McDonald, K. C., Melillo, J. M., Romanovsky, V. E., and Smith, N. V.: Importance of recent shifts in soil thermal dynamics on growing season length, productivity, and carbon sequestration in terrestrial high-latitude ecosystems, Global Change Biol., 12, 731750, 2006.

Farquhar, G. D., von Caemmerer, S., and Berry, J. A.: A biochemical model of photosynthetic $\mathrm{CO}_{2}$ assimilation in leaves of $\mathrm{C}_{3}$ species, Planta, 149, 78-90, 1980.

Friedlingstein, P., Cox, P., Betts, R., Bopp, L., von Bloh, W., Brovkin, V., Cadule, P., Doney, S., Eby, M., Fung, I., Bala, G., John, J., Jones, C., Joos, F., Kato, T., Kawamiya, M., Knorr, W., Lindsay, K., Matthews, H. D., Raddatz, T., Rayner, P., Reick, C., Roeckner, E., Schnitzler, K. G., Schnur, R., Strassmann, K., Weaver, A. J., Yoshikawa, C., and Zeng, N.: Climate-carbon cycle feedback analysis: Results from the $\mathrm{C}^{4} \mathrm{MIP}$ model intercomparison, J. Climate, 19, 3337-3353, 2006.

Goetz, S. J., Epstein, H. E., Alcaraz, D., Beck, P., Bhatt, U., Bunn, A. G., Comiso, J., Jia, G. J., Kaplan, J. O., Lischke, H., Lloyd, A. H., Yu, Q., Walker, D. A.: Recent changes in arctic vegetation: satellite observations and simulation model predictions, in: 
Eurasian Arctic Land Cover and Land Use in a Changing Climate, edited by: Gutman, G. and Reissell, A., Springer, ISBN 978-90-481-9117-8, 2011.

Gurney, K. R., Baker, D., Rayner, P., Denning, S., Law, R., Bousquet, P., Bruhwiler, L., Chen, Y. H., Ciais, P., Fung, I., Heimann, M., John, J., Maki, T., Maksyutov, S., Peylin, P., Prather, M., Pak, B., and S. Taguchi, S.: Interannual variations in continental-scale net carbon exchange and sensitivity to observing networks estimated from atmospheric $\mathrm{CO}_{2}$ inversions for the period 1980-2005, Global Biogeochem. Cy., 22, GB3025, doi:10.1029/2007GB003082, 2008.

Gurney, K. R: Global atmospheric carbon budget, Biogeosciences, in preparation, 2012.

Haxeltine, A. and Prentice, I. C.: A general model for the lightuse efficiency of primary production, Funct. Ecol., 10, 551-561, 1996.

Hayes, D. J., McGuire, A. D., Kicklighter, D. W., Gurney, K. R., Burnside, T. J., and Melillo, J. M.: Is the northern high latitude land-based $\mathrm{CO}_{2}$ sink weakening?, Global Biogeochem. Cy., 25, GB3018, doi:10.1029/2010GB003813, 2011.

Hickler, T., Vohland, K., Feehan, J., Miller, P. A., Smith, B., Costa, L., Giesecke, T., Fronzek, S., Cramer, W., and Sykes, M.: Projecting the future distribution of European potential natural vegetation with a generalized tree-species-based dynamic vegetation model, Global Ecol. Biogeogr., 21, 50-63, 2012.

Hinzman, L. D., Bettez, N. D., Bolton, W. R., Chapin, F. S., Dyurgerov, M. B., Fastie, C. L., Griffith, B., Hollister, R. D., Hope, A., Huntington, H. P., Jensen, A. M., Jia, G. J., Jorgenson, T., Kane, D. L., Klein, D. R., Kofinas, G., Lynch, A. H., Lloyd, A. H., McGuire, A. D., Nelson, F. E., Nolan, M., Oechel, W. C., Osterkamp, T. E., Racine, C. H., Romanovsky, V. E., Stone, R. S., Stow, D. A., Sturm, M., Tweedie, C. E., Vourlitis, G. L., Walker, M. D., Walker, D. A., Webber, P. J., Welker, J. M., Winker, K. S., and Yoshikawa, K.: Evidence and implications of recent climate change in northern Alaska and other Arctic regions, Climatic Change, 72, 251-298, 2005.

Jackowicz-Korczynski, M., Christensen, T. R., Backstrand, K., Crill, P., Friborg, T., Mastepanov, M., and Ström, L.: Annual cycle of methane emission from a subarctic peatland, J. Geophys. Res.-Biogeo., 115, G02009, doi:10.1029/2008JG000913, 2010.

Karlsen, S. R., Høgda, K. A., Wielgolaski, F. E., Tolvanen, A., Tømmervik, H., Poikolainen, J., and Kubin, E.: Growing-season trends in Fennoscandia 1982-2006, determined from satellite and phenology data, Clim. Res., 39, 275-286, 2009.

Kim, Y., Kimball, J. S., Zhang, K., and McDonald, K.C.: Satellite detection of increasing northern hemisphere non-frozen seasons from 1979 to 2008: Implications for regional vegetation growth, Remote Sens. Environ., 12, 472-487, 2012.

Kimball, J. S., Jones, L. A., Zhang, K., Heinsch, F. A., McDonald, K. C., and Oechel, W. C.: A satellite approach to estimate landatmosphere $\mathrm{CO}_{2}$ exchange for Boreal and Arctic biomes using MODIS and AMSR-E, IEEE T. Geosci. Remote, 47, 569-587, doi:10.1109/TGRS.2008.2003248, 2009.

Koven, C., Friedlingstein, P., Ciais, P., Khvorostyanov, D., Krinner, G., and Tarnocai, C.: On the formation of high-latitude soil carbon stocks: Effects of cryoturbation and insulation by organic matter in a land surface model, Geophys. Res. Lett., 36, L21501, doi:10.1029/2009GL040150, 2009.
Koven, C. D., Ringeval, B., Friedlingstein, P., Ciais, P., Cadule, P., Khvorostyanov, D., Krinner, G., and Tarnocai, C.: Permafrost carbon-climate feedbacks accelerate global warming, P. Natl. Acad. Sci., 108, 14769-14774, doi:10.1073/pnas.1103910108, 2011.

Lawrence, D. M., Oleson, K. W., Flanner, M. G., Thornton, P. E., Swenson, S. C., Lawrence, P. J., Zeng, X., Yang, Z.-L., Levis, S., Sakaguchi, K., Bonan, G. B., and Slater, A. G.: Parameterization improvements and functional and structural advances in version 4 of the Community Land Model, J. Adv. Model. Earth Syst., 3, M03001, doi:10.1029/2011MS000045, 2011.

Levy, P. E., Cannell, M. G. R., and Friend, A. D.: Modelling the impact of future changes in climate, $\mathrm{CO}_{2}$ concentration and land use on natural ecosystems and the terrestrial carbon sink, Global Environ. Chang., 14, 21-30, 2004.

McDonald, K. C., Kimball, J. S., Njoku, E., Zimmermann, R., and Zhao, M.: Variability in springtime thaw in the terrestrial high latitudes: Monitoring a major control on the biospheric assimilation of atmospheric $\mathrm{CO}_{2}$ with spaceborne microwave remote sensing, Earth Interact., 8, 1-23, 2004.

McGuire, A. D., Melillo, J. M., Joyce, L. A., Kicklighter, D. W., Grace, A. L., Moore III, B., and Vörösmarty, C. J.: Interactions between carbon and nitrogen dynamics in estimating net primary productivity for potential vegetation in North America, Global Biogeochem. Cy., 6, 101-124, 1992.

McGuire, A. D., Melillo, J. M., Kicklighter, D. W., Pan, Y., Xiao, X., Helfrich, J., Moore III, B., Vorosmarty, C. J., and Schloss, A. L.: Equilibrium responses of global net primary production and carbon storage to doubled atmospheric carbon dioxide: Sensitivity to changes in vegetation nitrogen concentration, Global Biogeochem. Cy., 11, 173-189, 1997.

McGuire, A. D., Clein, J. S., Melillo, J. M., Kicklighter, D. W., Meier, R. A., Vorosmarty, C. J., and Serreze, M. C.: Modelling carbon responses of tundra ecosystems to historical and projected climate: sensitivity of pan-Arctic carbon storage to temporal and spatial variation in climate, Global Change Biol., 6, S141-S159, 2000.

McGuire, A. D., Anderson, L. G., Christensen, T. R., Dallimore, S., Guo, L., Hayes, D. J., Heimann, M., Lorenson, T. D., Macdonald, R. W., and Roulet, N.: Sensitivity of the carbon cycle in the Arctic to climate change, Ecol. Monogr., 79, 523-555, 2009.

McGuire, A. D., Hayes, D. J., Kicklighter, D. W., Manizza, M., Zhuang, Q., Chen, M., Follows, M. J., Gurney, K. R., McClelland, J. W., Melillo, J. M., Peterson, B. J., and Prinn, R.: An analysis of the carbon balance of the Arctic Basin from 1997 to 2006, Tellus B, 62, 455-474, doi:10.1111/j.1600-0889.2010.00497.x, 2010.

Merbold, L., Kutsch, W. L., Corradi, C., Kolle, O., Rebmann, C., Stoy, P. C., Zimov, S. A., and Schulze, E. D.: Artificial drainage and associated carbon fluxes $\left(\mathrm{CO}_{2} / \mathrm{CH}_{4}\right)$ in a tundra ecosystem, Global Change Biol., 15, 2599-2614, 2009.

Nemani, R. R., Keeling, C. D., Hashimoto, H., Jolly, W. M., Piper, S. C., Tucker, C. J., Myneni, R. B., and Running, S.W.: Climatedriven increases in global terrestrial net primary production from 1982 to 1999, Science, 300, 1560-1563, 2003.

New, M., Hulme, M., and Jones, P. D.: Representing twentiethcentury space-time climate variability, Part I: development of a 1961-90 mean monthly terrestrial climatology, J. Climate, 12, 829-856, 1999. 
Oechel, W. C., Hastings, S. J., Vourlitis, G., Jenkins, M., Riechers, G., and Grulke, N.: Recent change of Arctic tundra ecosystems from a net carbon dioxide sink to a source, Nature, 361, 520-523, 1993.

Parmentier, F. J. W., van der Molen, M. K., van Huissteden, J., Karsanaev, S. A., Kononov, A. V., Suzdalov, D. A., Maximov, T. C., and Dolman, A. J.: Longer growing seasons do not increase net carbon uptake in the northeastern Siberian tundra, J. Geophys. Res., 116, G04013, doi:10.1029/2011JG001653, 2011.

Parmesan, C.: Influence of species, latitudes, and methodologies on estimates of phenological response to global warming, Global Change Biol., 13, 1860-1872, 2007.

Petrescu, A. M. R., van Beek, L. P. H., van Huissteden, J., Prigent, C., Sachs, T., Corradi, C. A. R., Parmentier, F. J. W., and Dolman, A. J.: Modeling regional to global $\mathrm{CH}_{4}$ emissions of boreal and arctic wetlands, Global Biogeochem. Cy., 24, GB4009, doi:10.1029/2009GB003610, 2010.

Piao, S., Ciais, P., Friedlingstein, P., Peylin, P., Reichstein, M., Luyssaert, S., Margolis, H., Fang, J., Barr, A., Chen, A., Grelle, A., Hollinger, D. Y., Laurilla, T., Lindroth, A. Richardson, A. D., and Vesala, T.: Net carbon dioxide losses of northern ecosystems in response to autumn warming, Nature, 451, 49-52, doi:10.1038/nature06444, 2008.

Piao, S., Wang, X., Ciais, P., Zhu, B., Wang, T., and Liu, J.: Changes in satellite-derived vegetation growth trend in temperate and boreal Eurasia from 1982-2006, Global Change Biol., 17, 32283239, doi:10.1111/j.1365-2486.2011.02419.x, 2011.

Ping, C. L., Michaelson, G. J., Jorgenson, M. T., Kimble, J. M., Epstein, H., Romanovsky, V. E., Walker, D. A.: High stocks of soil organic carbon in the North American Arctic region, Nat. Geosci., 1, 615-619, 2008.

Post, E., Forchhammer, M. C., Bret-Harte, S., Callaghan, T. V., Christensen, T. R., Elberling, B., Fox, A. D., Gilg, O., Hik, D. S., Hoye, T. T., Ims, R. A., Jeppesen, E., Klein, D. R., Madsen, J., McGuire, A. D., Rysgaard, S., Schindler, D. E., Stirling, I., Tamstorf, M. P., Tyler, N. J. C., van der Wal, R., Welker, J., Wookey, P. A., and Aastrup, P.: Ecological dynamics across the Arctic associated with recent climate change, Science, 325, 1355-1358, 2009.

Poutou, E., Krinner, G., Genthon, C., and de Noblet-Ducoudre, N.: Role of soil freezing in future boreal climate change, Clim. Dyn., 23, 621-639, 2004.

Qian, H., Renu, J., and Zeng, N.: Enhanced terrestrial carbon uptake in the northern high latitudes in the 21 st century from the coupled carbon cycle climate model intercomparison project model projections, Global Change Biol., 16, 641-656, doi:10.1111/j.13652486.2009.01989.x, 2010

Rawlins, M. A., Steele, M., Holland, M. M., Adam, J. C., Cherry, J. E., Francis, J. A., Groisman, P. Y., Hinzman, L. D., Huntington, T. G., Kane, D. L., Kimball, J. S., Kwok, R., Lammers, R. B., Lee, C. M., Lettenmaier, D. P., McDonald, K. C., Podest, E., Pundsack, J. W., Rudels, B., Serreze, M. C., Shiklomanov, A., Skagseth, Ø., Troy, T. J., Vörösmarty, C. J., Wensnahan, M., Wood, E. F., Woodgate, R., Yang, D., Zhang, K., and Zhang, T.: Analysis of the Arctic system for freshwater cycle intensification: Observations and expectations, J. Climate, 23, 5716-5737, doi:10.1175/2010JCLI3421.1, 2010.

Ringeval, B., de Nobletâ, N., Ducoudré, A. R., Ciais, P., Bousquet, P., Prigent, C., Papa, F., and Rossow, W. B.: An attempt to quan- tify the impact of changes in wetland extent on methane emissions on the seasonal and interannual time scales, Global Biogeochem. Cy., 24, GB2003, doi:10.1029/2008GB003354, 2010.

Rinne, J., Riutta, T., Pihlatie, M., Aurela, M., Haapanala, S., Tuovinen, J., Tuittila, E., and Versala, T.: Annual cycle of methane emission from a boreal fen measured by the eddy covariance technique, Tellus B, 59, 449-457, 2007.

Rowland, J. C., Jones, C. E., Altmann, G., Bryan, R., Crosby, B. T., Geernaert, G. L., Hinzman, L. D., Kane, D. L., Lawrence, D. M., Mancino, A., Marsh, P., McNamara, J. P., Romanovsky, V. E., Toniolo, H., Travis, J., Trochim, E., and Wilson, C. J.: Arctic landscapes in transition: Responses to thawing permafrost, Eos, 91, 229-230, 2010.

Running, S. W., Nemani, R. R., Heinsch, F. A., Zhao, M., Reeves, M., and Hashimoto, H.: A continuous satellite-derived measure of global terrestrial primary productivity: Future science and applications, Bioscience, 56, 547-560, 2004.

Schaefer, K., Zhang, T., Bruhwiler, L., and Barrett, A. P.: Amount and timing of permafrost carbon release in response to climate warming, Tellus B, 63, 165-180, 2011

Schneider von Deimling, T., Meinshausen, M., Levermann, A., Huber, V., Frieler, K., Lawrence, D. M., and Brovkin, V.: Estimating the near-surface permafrost-carbon feedback on global warming, Biogeosciences, 9, 649-665, doi:10.5194/bg-9-649-2012, 2012.

Schuur, E., Bockheim, J., Canadell, J., Euskirchen, E., Field, C., Goryachkin, S., Hagemann, S., Kuhry, P., Lafleur, P., and Lee, H.: Vulnerability of permafrost carbon to climate change: Implications for the global carbon cycle, Bioscience, 58, 701-714, 2008.

Schuur, E. A. G., Abbott, B. W., Bowden, W. B., Brovkin, V., Camill, P., Canadell, J. P., Chapin III, F. S., Christensen, T. R., Chanton, J. P., Ciais, P., Crill, P. M., Crosby, B. T., Czimczik, C. I., Grosse, G., Hayes, D. J., Hugelius, G., Jastrow, J. D., Kleinen, T., Koven, C. D., Krinner, G., Kuhry, P., Lawrence, D. M., Natali, S. M., O’Donnell, J. A., Ping, C. L., Rinke, A., Riley, W. J., Romanovsky, V. E., Sannel, A. B. K., Schädel, C., Schaefer, K., Subin, Z. M., Tarnocai, C., Turetsky, M., Walter-Anthony, K. M., Wilson, C. J., and Zimov, S. A.: High risk of permafrost thaw, Nature, 480, 32-33, 2011

Serreze, M. C., Bromwich, D. H., Clark, M. P., Etringer, A. J., Zhang, T., and ammers, R.: Large-scale hydro-climatology of the terrestrial Arctic drainage system, J. Geophys. Res., 108, 8160, doi:10.1029/2001JD000919, 2003

Shaver, G. R., Billings, W. D., Chapin, F. S., Giblin, A. E., Nadelhoffer, K. J., Oechel, W. C., and Rastetter, E. B.: Global change and the carbon balance of Arctic ecosystems, Bioscience, 42 433-441, 1992.

Sitch, S., Smith, B., Prentice, I. C., Arneth, A., Bondeau, A., Cramer, W., Kaplan, J., Levis, S., Lucht, W., Sykes, M., Thonicke, K., and Venevsky, S.: Evaluation of ecosystem dynamics, plant geography and terrestrial carbon cycling in the LPJ Dynamic Global Vegetation Model, Global Change Biol., 9, 161185,2003

Sitch, S., McGuire, A. D., Kimball, J., Gedney, N., Gamon, J., Engstrom, R., Wolf, A., Zhuang, Q., Clein, J. S., and McDonald, K. C.: Assessing the carbon balance of circumpolar arctic tundra using remote sensing and process modeling, Ecol. Appl., 17, 213-234, 2007. 
Sitch, S., Huntingford, C., Gedney, N., Levy, P. E., Lomas, M., Piao, S. L., Betts, R., Ciais, P., Cox, P., and Friedlingstein, P.: Evaluation of the terrestrial carbon cycle, future plant geography and climate-carbon cycle feedbacks using five Dynamic Global Vegetation Models (DGVMs), Global Change Biol., 14, 2015-2039, 2008.

Smith, B., Prentice, I. C., and Sykes, M. T.: Representation of vegetation dynamics in modelling of terrestrial ecosystems: Comparing two contrasting approaches within European climate space, Global Ecol. Biogeogr., 10, 621-637, 2001.

Sörlin, S. and Danell, K.: 1st IPY Workshop on Sustaining Arctic Observing Networks: Workshop Report, available at: http://www.arcticobserving.org/images/stories/workshop_report/ SAON1_report_total.pdf, 2008.

Snow, Water, Ice, and Permafrost in the Arctic (SWIPA) Assessment: Executive Summary, Arctic Monitoring and Assessment Program (AMAP) Secretariat. Oslo, Norway, available at: www. amap.no, 16 pp., 2011.

Tarnocai, C., Canadell, J. G., Schuur, E. A. G., Kuhry, P., Mazhitova, G., and Zimov, S.: Soil organic carbon pools in the northern circumpolar permafrost region, Global Biogeochem. Cy., 23, GB2023, doi:10.1029/2008GB003327, 2009.

Thornton, P. E., Lamarque, J. F., Rosenbloom, N. A., and Mahowald, N. M.: Influence of carbon-nitrogen cycle coupling on land model response to $\mathrm{CO}_{2}$ fertilization and climate variability, Global Biogeochem. Cy., 21, GB4018, doi:10.1029/2006GB002868, 2007.

Thornton, P. E., Doney, S. C., Lindsay, K., Moore, J. K., Mahowald, N., Randerson, J. T., Fung, I., Lamarque, J.-F., Feddema, J. J., and Lee, Y.-H.: Carbon-nitrogen interactions regulate climate-carbon cycle feedbacks: results from an atmosphereocean general circulation model, Biogeosciences, 6, 2099-2120, doi:10.5194/bg-6-2099-2009, 2009.

Vlassova, T. K.: Human Impacts on the Tundra-Taiga Zone Dynamics: The case of the Russian Lesotundra, Ambio Special Report (Tundra-Taiga Treeline Research), 12, 30-36, 2002.

Wania, R., Ross, I., and Prentice, I. C.: Integrating peatlands and permafrost into a dynamic global vegetation model: I. Evaluation and sensitivity of physical land surface processes, Global Biogeochem. Cy., 23, GB3014, doi:10.1029/2008GB003412, 2009a.

Wania, R., Ross, I., and Prentice, I. C.: Integrating peatlands and permafrost into a dynamic global vegetation model: II. Evaluation and sensitivity of vegetation and carbon cycle processes, Global Biogeochem. Cy., 23, GB015, doi:10.1029/2008GB003413, 2009b.
Wania, R., Ross, I., and Prentice, I. C.: Implementation and evaluation of a new methane model within a dynamic global vegetation model: LPJ-WHyMe v1.3.1, Geosci. Model Dev., 3, 565-584, doi:10.5194/gmd-3-565-2010, 2010.

Woodward, F. I., Smith, T. M., and Emanuel, W. R.: A global land primary productivity and phytogeography model, Global Biogeochem. Cy., 9, 471-490, 1995.

Woodward, F. I. and Lomas, M. R.: Vegetation dynamics: simulating responses to climate change, Biol. Rev., 79, 643-670, 2004.

Zaehle, S. and Friend. A. D.: Carbon and nitrogen cycle dynamics in the O-CN land surface model: 1. Model description, sitescale evaluation and sensitivity to parameter estimates, Global Biogeochem. Cy., 24, GB1005, doi:1010.1029/2009GB003521, 2010.

Zhang, K., Kimball, J. S., Hogg, E. H., Zhao, M., Oechel, W. C., Cassano J. J., and Running, S. W.: Satellite-based model detection of recent climate driven changes in northern high latitude vegetation productivity, J. Geophys. Res., 113, G03033, doi:101029/2007JG000621, 2008.

Zhao, M. and Running, S. W.: Drought-induced reduction in global terrestrial net primary production from 2000-2009, Science, 329, 940-943, 2010.

Zhuang, Q., Romanovsky, V. E., and McGuire, A. D.: Incorporation of a permafrost model into a large-scale ecosystem model: Evaluation of temporal and spatial scaling issues in simulating soil thermal dynamics, J. Geophys. Res.-Atmos., 106, 33649-33670, 2001.

Zhuang, Q., McGuire, A. D., Melillo, J. M., Clein, J. S., Dargaville, R. J., Kicklighter, D. W., Myneni, R. B., Dong, J., Romanovsky, V. E., Harden, J., and Hobbie, J. E.: Carbon cycling in extratropical terrestrial ecosystems of the Northern Hemisphere during the 20th century: a modeling analysis of the influences of soil thermal dynamics, Tellus B, 55, 751-776, 2003.

Zhuang, Q., Melillo, J. M., Kicklighter, D. W., Prinn, R. G., McGuire, A. D., Steudler, P. A., Felzer, B. S., and Hu, S.: Methane fluxes between terrestrial ecosystems and the atmosphere at northern high latitudes during the past century: A retrospective analysis with a process-based biogeochemistry model, Global Biogeochem. Cy., 18, GB3010, doi:10.1029/2004GB002239, 2004.

Zhuang, Q., Melillo, J. M., McGuire, A. D., Kicklighter, D. W., Prinn, R. G., Steudler, P. A., Felzer, B. S., and Hu, S.: Net emissions of $\mathrm{CH}_{4}$ and $\mathrm{CO}_{2}$ in Alaska: Implications for the region's greenhouse gas budget, Ecol. Appl., 17, 203-212, 2007. 